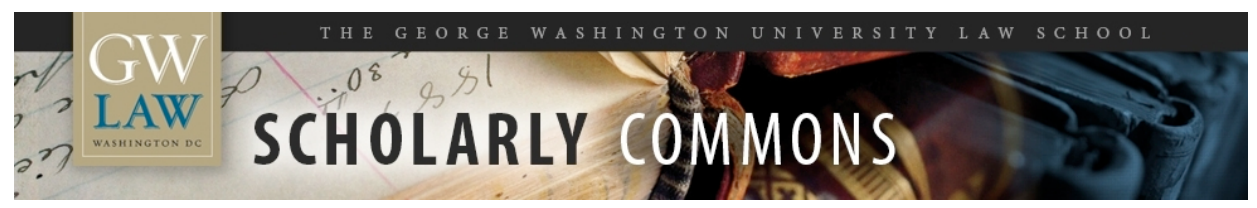

\title{
Strange Bedfellows? Representative Democracy and Academic Engagement with the Defense Industry
}

Steven L. Schooner

Evan Matsuda

Follow this and additional works at: https://scholarship.law.gwu.edu/faculty_publications

Part of the Law Commons 


\section{PART V}

Conclusion 


\title{
17. Strange Bedfellows? Representative Democracy and Academic Engagement with the Defense Industry
}

\author{
Steven L. Schooner and Evan Matsuda
}

\section{Introduction: Gee, This Seems Important}

"What gets measured gets managed" is a popular mantra among government performance management advocates. ${ }^{1}$ In representative democracy, the converse might be "out of sight, out of mind." How did the United States come to be a government, originally created to be responsive to the will of its people, that boasts the world's most powerful military, spends more scarce resources on its military than any other, and exports the most kinetic capacity? How can such a public not study, research, analyze, think, and talk about the ethical aspects of its defense industry?

\section{Ms. Frizzle Was Right: Question Everything ${ }^{2}$}

In his iconic piece, Lighthouse No Good, ${ }^{3}$ William Prosser chronicled an intriguing, if slightly disorienting, career in legal education. Prosser begins:

Lighthouse, him no good for fog.

Lighthouse, him whistle, him blow, him ring bell, him flash light, him raise hell;

but fog come in just the same.

He then meanders his way to an unnerving epiphany, in which an aging, truthful professor responds to the query: "How do you teach law?" as he was himself answered so many years before: "I don't know. None of us knows."4

But experience, at a minimum, reveals how not to teach law. For example, when teaching issues related to defense acquisition, government contracts, and the policies that animate "the

\footnotetext{
${ }^{1}$ For an accessible example of the literature, see KATHERINE BARRETT \& RICHARD GREENE, MAKING GOVERNMENT Work: The PROMISES AND Pitfalls OF PERFormanCE-INFORMED MANAGEMENT (2020). For a critique of the mantra, see John Kamensky, Does Performance Matter?, IBM CTR. FOR BUS. GOV'T (Mar. 28, 2016) (citing Ed Gerrish, The Impact of Performance Management in Public Organizations: A Meta-Analysis, 76 PUB. AdMIN. ReV. 48 (2015)), https://www.businessofgovernment.org/blog/does-performance-matter.

2 "Get messy, take chances, make mistakes!" exhorts Ms. Frizzle, voiced by the incomparable Lily Tomlin. The Magic School Bus (Scholastic 1994-1997).

${ }^{3}$ William L. Prosser, Lighthouse No Good, 1 J. LEGAL EDUC. 257, 257 (1948) (recounting a quotation reportedly "spoken by a West Coast Indian, sitting on a rock and looking out to sea"). When one of us left his procurement policy job to become a full-time academic, his spouse, who had previously joined the legal academy, recommended the Prosser piece. Regardless of whether or not either of us understood the piece, it did make us think.

${ }^{4} I d$. at 264 (emphasis added).
} 
business of government," it is a fool's errand to expect students to learn all of the relevant rules. Not only are there far too many, but Congress can - and frequently does - change (or supplement or delete or replace) them. Conversely, students benefit enormously if they learn how to interpret and implement rules. And they most rapidly ascend the learning curve if they can identify and understand the underlying policies that animate the rules.

This book offers students, the academy, defense industry professionals, and policymakers a wonderful opportunity to question many things we take for granted about the defense industry. Focusing on the underlying policies, and asking the why question, rather than simply how or what, is a valuable exercise because the military enterprise, the defense industry, and the market that binds private sector contractors with government customers are sprawling, impenetrable to the uninitiated, overwhelming to the casual observer, and riddled with inconsistent policies. For example, in our classrooms, students learn that:

- On one hand, statute and regulation demand that government contractors maintain complex, sophisticated, and costly compliance regimes. On the other hand, Congress mandates that nearly a quarter of all procurement dollars be funneled to small businesses that frequently lack the resources to establish effective compliance programs or the wherewithal to appreciate the risk of doing business without them. ${ }^{5}$

- The primary regulatory guidance makes clear that "[b]oth the Government and contractors should be concerned with profit as a motivator of efficient and effective contract performance."6 However, congressional rhetoric and longstanding norms celebrate minimizing contractor profit, and contractors supporting the military in the

\footnotetext{
${ }^{5}$ See, generally, FAR Subpart 9.1 for the premise that the government should only do business with "responsible" contractors and Subpart 9.4, which discusses debarment, suspension, and ineligibility. Not surprisingly, a generation of empirical data demonstrates that, while large, important contractors are almost never blacklisted or excluded from competing for government work, staggering numbers of small (and, apparently, dispensable) small businesses are routinely suspended, proposed for debarment, and debarred. In Chapter 14, Chris Yukins eloquently demonstrates this asymmetry: "[A] firm without an effective compliance system in place . . . is left exposed to potentially disastrous risks, both of substantive violations and of failing to make the mandated disclosure of those violations. In sum, the mandatory disclosure rule exacerbates the competitive disadvantages borne by small- and medium-sized enterprises." Yukins at __. In Chapter 15, Jessica Tillipman, along with Vijaya Surampudi, remind us that, while some of these disparities can be reduced, it is unrealistic to assume them away: "Large contractors make significant investments in their ethics and compliance programs, and some view their programs as proprietary and confidential. Many contractors fear that competitors will exploit this information if they share it publicly. Yet, by depriving small businesses access to this information and resources, the large contractors may ultimately be harmed if the suppliers suffer from compliance deficiencies or failures." Tillipman \& Surampudi at notes 61-63 regarding these compliance programs.

${ }^{6}$ FAR 15.404-4(a)(3). Many find this medicine difficult to swallow. For example, in Chapter 1, Tobias Vestner asserts that "the main ethical issue relates to the product: weapons and military technologies are tools to kill people. Making profits from this activity is problematic as a matter of principle . . . "Vestner at _ (16). Putting aside how this perspective might apply to the (admittedly dubious) ethics of the National Rifle Association (NRA) and its members, including the domestic handgun and rifle manufacturers, which are beyond the scope of this chapter and book, severing the profit motive from defense contracting feels analogous to the increasingly quaint aspiration that the government maintain a monopoly over the use of force but, alas, runs contrary to the conventional incentives underlying outsourcing, reliance on the private sector, and, ultimately, capitalism.
} 
battlefield are described pejoratively as "profiteers."

- It is government policy to consolidate its purchasing requirements to achieve the benefits of economies of scale, but at the same time it is prohibited by law to aggregate or consolidate or "bundle" purchases that would make it impossible for small business to compete for the government's business. ${ }^{8}$

Complexity is a given in the defense industry, ${ }^{9}$ and that complexity gives rise to fascinating, frustrating, difficult, and nuanced questions. But complexity and conflicting priorities afford no justification for avoiding academic discourse. To the contrary, when the U.S. government maintains such a massive kinetic arsenal, boasts the world's largest military budget,

\footnotetext{
${ }^{7}$ Indeed, for nearly a quarter of the twentieth century, Congress created and sustained a "Renegotiation Board," which retroactively clawed back "excessive" contractor profits. The board plied its trade from 1951 until 1979. Senate Vote Means End of Renegotiation Board, N.Y. TiMEs (Apr. 3, 1979), https://www.nytimes.com/1979/04/03/archives/senate-vote-means-end-of-renegotiation-board.html; Renegotiation Board—Reporting Requirement (50 U.S.C. App. § 1215) —Effect of Absence of an Appropriation—Repeals by Implication, 3 Op. O.L.C. 318 (1979), https://www.justice.gov/file/22096/download. See also Tobias Vestner's Chapter 1 riff on defense contractor profits, supra note 6 . Although the rationale for this phenomenon is beyond the scope of this chapter, we would be remiss if we failed to mention than many significant government contractorsfor example, most academic institutions - are not-for-profit entities.
}

${ }^{8}$ See, e.g., FAR 2.101 (defining "bundling" as "a subset of consolidation that combines two or more requirements for supplies or services, previously provided or performed under separate smaller contracts . . into a solicitation for a single contract ... or . . . order that is likely to be unsuitable for award to a small business concern"). But see FAR 7.107-2 (“Consolidation may provide substantial benefits to the Government.").

${ }^{9}$ Indeed, we might fill another book with debate surrounding the definition and scope of "the defense industry." Tobias Vestner, in Chapter 1, helpfully informs a potential, thematic definition by focusing on the defense industry's contribution to national security. We gravitate towards (and write in the context of) a broad and inclusive definition of the terms "military industrial base" or "defense industrial base sector," the latter of which "provides products and services that are essential to mobilize, deploy, and sustain military operations." Critical Infrastructure Sectors, CYBERSECURITY \& INFRASTRUCTURE SEC. AGENCY (emphasis added), https://www.cisa.gov/defense-industrialbase-sector (last visited Jan. 9, 2022); see also, HeIDI M. PETERs, CONG. RSCH. SERV., IF10548, DefENSE PRIMER: U.S. DEFENSE INDUSTRIAL BASE (2021), https://crsreports.congress.gov/product/pdf/IF/IF10548/10 (explaining that DoD "relies on a wide-ranging and complex industrial base for the products and services that enable the Department's warfighting capabilities" and that "[d]efinitions of what this industrial base encompasses vary in scope and emphasis"(emphasis added)). CRS further explains:

$[T]$ hese entities provide a wide range of products and services to the DOD, encompassing everything from complex platforms unique to the military (e.g., aircraft carriers) and highly specialized services (such as launching military satellites), to all kinds of commercial products (e.g., laptop computers and semiconductors) and routine services (e.g., information technology (IT) support).

Id. This broad and inclusive definition is critical to this book's themes to the extent that: (1) for decades, defense procurement of services has significantly exceeded purchases of goods or supplies, and (2) the modern realities of outsourced defense - and the integration of, and reliance upon, service contractors in the battlespace - have dramatically changed everything from how the military projects lethality to the nature of "sacrifice" and who makes "the ultimate sacrifice." See, e.g., infra text accompanying notes 18, 50, 52, 88-89. 
sustains the world's largest defense industry, and leads the world in arms exports, ${ }^{10}$ the policy puzzles that pervade nearly every aspect of the defense industry take on even greater import. It would be imprudent to ignore such an impactful sector of the economy. ${ }^{11}$

Moreover, as Daniel Schoeni and Tobias Vestner remind in their Introduction, the ethical issues that permeate the defense industry and stimulate thinking in this volume are like "mowing the grass;" they "require our constant vigilance." 12 The hard work and thought-provoking issues are endless. For these reasons, we are flummoxed when academic institutions attempt to keep the defense industry not just at arm's length but out of reach and out of mind. Or, in other words, Prosser's lighthouse might fail to burn away the fog, but it still reveals dangers to passing ships and, in so doing, serves a valuable purpose.

For the post-Cold War generation, Eisenhower's familiar Military Industrial Complex warning ${ }^{13}$ evolved from harbinger to gospel. Academic opinion, informed by congressional oversight hearings, Government Accountability Office (GAO) and Inspector General (IG) reports, Department of Justice (DoJ) press releases, and media coverage, tended to counsel distance and detachment regarding the defense industry ${ }^{14}$ long before the popularity of "cancel

10 "The United States now spends more on defense than the next 11 spenders combined." HARVEY M. SAPOLSKY, Eugene Gholz \& Caitlin Talmadge, U.S Defense Politics: The Origins of National Security 5 (4th ed. 2021); see also 2021 Power Rankings, U.S. NEWS \& WORLD REP., https://www.usnews.com/news/bestcountries/power-rankings (last visited Aug. 22, 2021); Chiara Vercellone, Who Were the Largest Major Arms Exporters in the Last 5 Years?, DEF. NEWS (Mar. 9, 2020), https://www.defensenews.com/2020/03/09/who-werethe-largest-major-arms-exporters-in-the-last-5-years.

${ }^{11}$ See generally infra text accompanying note 35 .

${ }^{12}$ Schoeni \& Vestner at

${ }^{13}$ Dwight D. Eisenhower, Farewell Radio and Television Address to the American People (Jan. 17, 1961), in Public Papers of The President of the United States: DWight D. Eisenhower 1960-61, at 1035 (1961).

${ }^{14}$ During the Vietnam era, colleges and universities drove ROTC programs off campus. See Jean Marbella, ROTC Resurgent on College Campuses Where Once Scorned, BALT. Sun, (Nov. 18, 2001),

https:/www.baltimoresun.com/news/bs-xpm-2001-11-18-0111180052-story.html ("Many of the nation's elite universities, including Harvard, Yale, Columbia and Stanford, kicked ROTC off their campuses in protest of the Vietnam War."); Elizabeth Phelan, "A Watershed Moment”: Reflecting on the Burning of the ROTC Air Force Building-50 Years Later, STUDENT LIFE (May 5, 2020), https:/www.studlife.com/scene/2020/05/05/a-watershedmoment-reflecting-on-the-burning-of-the-rotc-air-force-building-50-years-later. Indeed, when one of us arrived at Rice University in the 1970's courtesy of an Army ROTC scholarship, he was surprised to find the ROTC detachment housed in a concrete bunker underneath the Central Kitchen on the edge of campus. A generation later, for different reasons, many law schools barred military (Judge Advocate General Corps) recruiters from campus. See generally Doug Lederman, Wrangling over Military Recruiting, INSIDE HIGHER ED (Feb. 3, 2005),

https:/www.insidehighered.com/news/2005/02/03/wrangling-over-military-recruiting. 
culture." ${ }^{15}$ Historical analogies to the tobacco industry come to mind, just as, looking ahead, we expect the academy to increasingly distance and divest itself from the fossil fuel industry. ${ }^{16}$

Given the importance of the defense industry to so many aspects of our lives, this brief chapter applauds and encourages academic engagement with the defense industry and robust discussion of, inter alia, the industry's composition, behavior, economic footprint and impact (and, in that context, incentives and disincentives), and role (whether as the state's business partner or, all too often, as a state actor) ${ }^{17}$ It is not just that these issues are ripe for debate or that they provide innumerable research opportunities. Rather, they are a critically important component of the kind of practical knowledge that citizenship in a representative democracy requires. Far too many caricatures of a unitary military industrial base and its motivations are uninformed, inaccurate, and unhelpful. Among other things, unlike cigarettes, sugar-saturated carbonated beverages, and gasoline, national defense is critical to national security, public safety,

\footnotetext{
${ }^{15}$ In reviewing our chapter, one of this volume's editors, Tobias Vestner, raised the specter of on-campus cancel culture. See, e.g., Conor Friedersdorf, The Destructiveness of Call-Out Culture on Campus, ATLANTIC (May 8, 2017), https://www.theatlantic.com/politics/archive/2017/05/call-out-culture-is-stressing-out-collegestudents/524679; Pippa Norris, Cancel Culture: Myth or Reality?, POL. STUD., July 16, 2021, at 1, https://journalssagepub-com.proxygw.wrlc.org/doi/pdf/10.1177/00323217211037023 ("The evidence suggests that the cancel culture is not simply a rhetorical myth; scholars may be less willing to speak up to their moral beliefs if they believe their views are not widely shared by colleagues ...."). While we consider the procedural aspects of advocacy, disagreement, and debate, including the innumerable forms of protest, beyond the scope of this chapter, we recognize the concern. In that context, we hope that the strength of our work and, indeed, this book, is measured by its merits rather than its proponents' identities. To that end, we agree with Vestner that, "in the context of ethical dilemmas, just because someone believes [themselves] to be right (and the other to be wrong) does not mean that the person is objectively right... . [I] f we lose our ability to debate and respect each other's opinion, we lose what it takes for a well-functioning democracy." Our agreement, however, extends only to "informed opinions." In discussing critically important issues related to defense, or for that matter climate change or responses to a global pandemic, we see more harm than good in elevating, promoting, respecting, or even tolerating "opinions" that deny science, ignore facts, or derive exclusively from unfounded, easily debunked conspiracy theories. See, e.g., Andy Norman, The Cause of America's Post-Truth Predicament, SCI. AM. (May 18, 2021), https://www.scientificamerican.com/article/the-cause-of-americas-post-truth-predicament ("When we affirm each other's 'right' to believe things - even things that fly in the face of evidence - we essentially decouple critical thinking and belief revision. This damages the norm that keeps minds tethered to reality.... [W]e must grasp that bad ideas are mind-parasites - entities that can proliferate and harm the very minds that host them. In fact, they can lay waste to delusion-tolerant cultures.").
}

16 "The most successful instance of higher ed divestment arguably occurred during South African apartheid, ... Today, colleges and universities face pressure to divest on a number of hot button issues, with recent efforts focused notably on fossil fuels and tobacco." Roger Riddell, Can Higher Ed Really Affect Change Through Divestment?, HiGHER ED DIVE (May 29, 2014), https://www.highereddive.com/news/can-higher-ed-really-affectchange-through-divestment/265675.

${ }^{17}$ No doubt, our biases are informed by our location (and a professional career, for one of us) in Washington, D.C. The business of government - and defense or, more broadly, national security - is fertile ground for research and study. Our classrooms and programming are enriched by connections to the national security and intelligence communities, the military, and the federal government in general. Indeed, the epicenter of all things defense is housed in the world's largest office building, just across the Potomac River and a mere three METRO stops away. Pentagon Facts, U.S. DEP'T OF DEF., https://pentagontours.osd.mil/Tours/facts.html; Michaila Hancock, Pentagon: The World's Largest Office Building - in Infographics, ARCHITECT's J. (Aug. 27, 2015), https://www.architectsjournal.co.uk/news/pentagon-the-worlds-largest-office-building-in-infographics. 
and, indeed, our very existence as a nation state. Meanwhile, we need to acknowledge the evolution of the "industry" - from weapons manufacturing to service providers ${ }^{18}$ — and reimagine the critical role the academy can play in crafting the modern defense industry's behaviors, norms, standards, aspirations, and, ultimately, ethics.

\section{A Sumptuous Menu}

The universe of important, thought-provoking ethical issues inherent throughout the defense industry merits discussion and study. Nonetheless, in teaching law and policy, it is easy for ethics to recede to the background. But once you open and walk through that door, the path skews to labyrinthian. Where does one even begin? Like perspectives, it probably depends upon how you categorize ethics.

If "national security" is your starting point, teleological ethics grounded in maintaining the state - or, more broadly, keeping the marauding hordes at bay-is an end that justifies dramatic means. ${ }^{19}$ The consequences of failing to fulfill the duty to defend the state dominate, suggesting a utilitarianism that excuses much (that, for example, a pacifist would neither condone nor stomach). For a simple litmus test, consider the U.S. government's resort to nuclear weapons to accelerate the end of World War II. ${ }^{20}$ To what lengths can one go to confront that which is evil? Whether this starts us down the slippery slope to economics and cost-benefit

\footnotetext{
18 Today's “defense industry" would be unrecognizable to World War-, Korea-, and even Vietnam-era veterans, policy officials, and academics. For example, the Federal Acquisition Regulation (FAR), promulgated in 1984, proceeds from the assumption that federal procurement is dominated by supplies or goods, treating services as a poorly regulated afterthought (and primarily focusing on labor relations). See generally 48 C.F.R. Today, services dominate. Indeed, service providers Leidos, L-3, and Honeywell were recently listed among the world's twenty largest defense contractors. Samuel Stebbins \& Evan Comen, Military Spending: 20 Companies Profiting the Most from War, USA TODAY (Feb. 21, 2019), https://www.usatoday.com/story/money/2019/02/21/military-spendingdefense-contractors-profiting-from-war-weapons-sales/39092315. More broadly, "[d]ollars spent on services contracts grew steadily throughout the 1990s . . . until dipping slightly in 2008. Since then, ... service contract spending rose in relation to overall DoD expenditures as spending on products decreased." Gregory Sanders et al., Defense Contract Trends: U.S. Department of Defense Contract Spending and the Supporting Industrial Base, CTR. FOR STRATEGIC \& INT'L STUD. 8 (2011), https://www.csis.org/analysis/defense-contract-trends-0; see also infra notes 50, 52; Richard L. Dunn, Defense Industry Needs New Way of Doing Business, NAT’L DEF. (Nov. 6, 2000), https://www.nationaldefensemagazine.org/articles/2020/11/6/defense-industry-needs-new-way-of-doing-business. See also supra note 9.
}

19 "Although modern Americans debate the legitimacy of many other ways that government may also contribute to the commonwealth, essentially everyone agrees that providing for the common defense is its first obligation. ... But in practice the national interest is a very slippery concept, and different people with different personal values define the national interest in different ways." SAPOLSKY ET AL., supra note 10, at 1 (emphasis added).

${ }^{20}$ If you happen to visit Albuquerque, New Mexico, we strongly recommend the National Museum of Nuclear Science \& History and its powerful Hiroshima and Nagasaki exhibit. Hiroshima and Nagasaki Exhibit, NAT'L MUSEUM OF NUCLEAR SCI. \& HIST., https://www.nuclearmuseum.org/see/exhibits/hiroshima-and-nagasaki (last visited Jan. 9, 2022). 
analysis is beyond the scope of this chapter. We know we all have our limits, but why? And where, with regard to our ethics or values, do we draw the line? ${ }^{21}$

For better or worse, it seems that Kant held sway in one of our superficial college philosophy courses, which, in hazy recollection, centered on deontological theories of ethics, universal moral laws, categorical imperatives, and what often seemed to be more binary questions of right versus wrong. Sure, lying is bad, and telling the truth is good, but that "golden rule" of "do unto others as you would have them do unto you" offered a comfortable touchstone or centering device. How that can be reconciled with the evolution (or, increasingly, devolution) of capitalism's winner-take-all social construct, again, exceeds this chapter's scope.

We concede that virtue-based ethics, focusing primarily on moral character, seem too fluid to provide clarity or guidance. As much as we find the aspiration of the virtuous life appealing - who would not value self-control, moderation, intelligence, pursuit of knowledge, courage, and justice? - the thread frays once cleanliness or frugality or punctuality came into play. Sure, it is rude to make others wait, but we are confident that most people would distinguish that from other virtues that seem to carry greater moral weight. And let us not forget that, from the Homeric tradition to modern-day recruiting, military service (and martial skill, nay excellence) is about as virtuous as it gets. Let us not confuse morality with character.

In another time, one might have expected America's two-decade military engagement in Afghanistan ${ }^{22}$ to generate a relentless focus on the ethics surrounding (and the morality of) the military's role abroad at some point prior to the August 2021 withdrawal that dramatically thrust the conflict back into the public spotlight. ${ }^{23}$ Nearly a half-century since the final military draft, ${ }^{24}$ teenagers register with the U.S. Selective Service System without anxiety, and students-like most of the public today — are further distanced from military service and all things defense-

\footnotetext{
${ }^{21}$ Anecdotes can be powerful and helpful, but, ultimately, they remain, well, anecdotal. History will reflect that the U.S. Central Intelligence Agency (CIA) should not have paid Dr. Bruce Jessen and Dr. James Mitchell more than $\$ 81$ million to devise rather brutal interrogation techniques, subsequently deemed to be illegal torture, yet, in pursuit of their perceived mission at the time, the CIA appeared to fully embrace the techniques. See generally Sheri Fink, Settlement Reached in C.I.A. Torture Case, N.Y. TIMES (Aug. 17, 2017), https:/www.nytimes.com/2017/08/17/us/cia-torture-lawsuit-settlement.html. Still, anecdotes are helpful in discussing values. "The question . . . is a values question rather than a question with a technically 'correct' answer. ... [H] [How much 'risk' should Americans tolerate, and how should they compare the importance of one risk (say, of a terrorist act against the United States) to another . . . . . [T] he answer is more subjective than scientific." SAPOLSKY ET AL., supra note 10, at 12.

22 "[T]he war [in Afghanistan] has run more than 19 years, longer than World War I, World War II and the Korean War combined." America's Longest War: A Visual History of 19 Years in Afghanistan, WALL ST. J. (Apr. 18, 2021), https://www.wsj.com/articles/us-longest-war-afghanistan-11583010024.

${ }^{23}$ See also infra note 89.

${ }^{24}$ Historical Timeline, SELECTIVE SERV. SYS., https://www.sss.gov/history-and-records/timeline (last visited Jan. 9, 2022) ("The last man inducted entered the Army on June 30, 1973.”).
} 
related than at any time in the nation's history. ${ }^{25}$ Indeed, college and graduate students today, the offspring and grandchildren of veterans of (or those who avoided service during) dubious military actions in Korea and Vietnam, grew up with little reason to pay attention to, understand, or ultimately care about the nation's "forever wars" in Afghanistan and Iraq. At the same time, current events - and the daily act of reading the news - offer frequent illustrations of the difference between what is right and wrong, what is legal and illegal, ${ }^{26}$ or, in practice, what some people can and do get away with, ${ }^{27}$ all of which provides valuable context for asking hard questions in the classroom.

So, yes, at times we struggle with incorporating the complex world of ethics, morality, and values into the work of teaching, studying, discussing, and analyzing the defense industry. In

${ }^{25}$ See David Zucchino \& David S. Cloud, Special Report: U.S. Military and Civilians Are Increasingly Divided, L.A. TIMES (May 23, 2015), https://www.latimes.com/nation/la-na-warrior-main-20150524-story.html ("Most of the country has experienced little, if any, personal impact from the longest era of war in U.S. history."); Bruce Drake, On Memorial Day, Public Pride in Veterans, but at a Distance, PEW RSCH. CTR. (May 24, 2013), https://www.pewresearch.org/fact-tank/2013/05/24/on-memorial-day-public-pride-in-veterans-but-at-a-distance-2 ("[T]he public that will be observing [Memorial Day] is also one increasingly disconnected from the military and the wars it fought since 2001 compared to those who lived through the wars of $20^{\text {th }}$ century."); Steven Aftergood, The Costs of War: Obstacles to Public Understanding, FED’n OF AM. SCIENTISTS (Nov. 14, 2018), https://fas.org/sgp/eprint/costs.pdf ("“P]ublic awareness of U.S. military operations [has been] diminished or eliminated rather than heightened. ... '[F]eedback loops' that are at the heart of deliberative democracy [have been] disabled. The public is not being forced, as it should be, to make difficult choices among competing priorities.").

${ }^{26}$ Before law school, as an undergraduate, one of us was exposed to many related issues through ROTC or "military science" classes. Although the text book spoke of "humane treatment of noncombatants," "human treatment of PW [or prisoners of war]," "humane treatment of civilians," and "criminal orders and individual responsibility" as legal mandates, the text also emphasized "the unwritten laws" also "known as the customary law of war[, the general purpose of which] . . . is to limit the suffering or destruction to military targets and to provide humane treatment for all persons who are taken out of the fight." See generally ROTCM 145-85, DEP'T OF ARMY, ROTC MANUAL, FUNDAMENTALS OF MILITARY LAW 82-104 (Oct. 1980). Even the hypotheticals (such as "the question of what to do if it seems to be a situation of "my life or his") have nicely stood the test of time. Id. at 100.

27 " The wealthy and powerful rarely go to jail, and, when they do, it is for relatively brief stays at 'Club Fed.' ... The rich and the powerful become richer and more powerful, while the public loses trust in our institutions. The accumulation of wealth and power is divorced from the means and the cost of that wealth generation, such as public ills ranging from degraded air and water quality, food poisoning, inflated consumer prices, reduced pension funds, opioid addition, poverty, social stratification and even suicide." Steven L. Schooner, We Need to Talk About Corruption, GOV’T EXEC. (Sept. 29, 2020) (reviewing JenNIFER TAUB, BIG DiRTY MONEY: THE SHOCKING INJUSTICE AND UNSEEN COST OF WHITE COLLAR CRIME (2020)), https://www.govexec.com/management/2020/09/we-need-talk-about-corruption/168857. The four years of the Trump administration introduced the American public to term "kleptocracy," and generated robust discussion of a never-ending succession of issues related to public service ethics. See generally SARAH KENDZIOR, HIDING IN PLAIN Sight: THE INVENTION OF DONALD TRUMP AND THE EROSION OF AMERICA (2020). Also, for a tip of the iceberg anecdote, see Steven L. Schooner, Kathleen Clark \& Scott Amey, Suspend the Trump Organization from Doing Business with Government, GOV'T EXEC. (Jan. 27, 2020), https://www.govexec.com/management/2020/01/viewpoint-suspend-trump-organization-doing-businessgovernment/162672. See also Letter from Noah Bookbinder, President, Citizens for Resp. \& Ethics, et al., to Bill Schmidt, Suspension \& Debarment Off., Gen. Servs. Admin., et al. (Oct. 12, 2021), https://www.citizensforethics.org/wp-content/uploads/2021/10/2021-10-12-Trump-Organization-SuspensionReferral.pdf ("[A]gencies routinely suspend contractors based on allegations of wrongdoing similar to (or less egregious than) those facing the Trump Organization, even when no criminal charges are pending."). 
the classroom, the far more mundane topic of compliance-discussed at length in several of the preceding chapters - resonates more clearly. No doubt, despite its lofty aspirations, compliance, upon closer examination, is more rule-based than ethics. In that context, Philip Nichols, in Chapter 9, makes a compelling case for why this book's work is so important:

Legal responsibility ... differs from moral duty. ... [Distinguishing what is legal and what is moral] is not a frivolous exercise. Exploring the moral responsibility of defense firms provides insights into the relationship between those firms and the rest of society, into the nature of defense markets, and into justifications for anti-corruption legal regimes. ...

... [In that context, with its unique opportunities for corruption, most agree that] firms owe primary duties to society at large and to potential victims of harm caused by the weapons and weapon systems that they sell. . . Society allows defense industry firms to accrue revenue for investors within this distorted market, but in exchange for society's forbearance, these firms must respect the basic human right to be safe. ${ }^{28}$

Maybe, as Richard Painter suggests in Chapter 4, before we discuss the responsibilities of defense contractors to comply with the U.S. arms export regime and ensure that the weapons they export meet the purchaser's quality control standards, we need to ask more fundamental questions: is there a clear ethical or moral justification for selling powerful weapons abroad? If

\footnotetext{
${ }^{28}$ Nichols at __. As Jeffrey Biller and Timothy Goines eloquently explain in Chapter 7, our digital livelihoods mean that our most fundamental understanding of the scope of human rights continues to evolve - in this case, rather rapidly. For a host of reasons, today, "digital data is a crucial component of most aspects of modern life and worthy of the highest levels of protection that the law can provide." Biller \& Goines at (15). For better or worse, one of the most challenging, vexing, and controversial topics in modern defense acquisition is the Defense Department's highly scrutinized effort to manage private sector cyber-security. See generally U.S. GoV'T ACCOUNTABILITY OFF., GAO-22-104679, DEFENSE CONTRACTOR CYBERSECURITY: STAKEHOLDER COMMUNICATION AND PERFORMANCE GOALS COULD IMPROVE CERTIFICATION FrAMEWORK (2021), https:/www.gao.gov/assets/gao-22-104679.pdf ("DOD Has Not Met Initial Implementation Goals or Sufficiently Communicated Key Decisions to Industry”); HeIDI M. Peters, Cong. RsCH. SERV., R46643, DefEnSE ACQUISITIONS: DOD's CYBERSECURITY MATURITY MODEL CERTIFICATION FRAMEWORK (2020) https://crsreports.congress.gov/product/pdf/R/R46643/2, (acknowledging criticism that, among other things, (1) "DOD efforts to mitigate cybersecurity risks and vulnerabilities [have been] fragmentary and reactive to specific issues or emerging concerns, with the potential to create 'confusion' within the defense industrial base as contractors attempt to meet 'ever-changing' requirements seen by some within the industry as costly and overly burdensome," and (2) "the current system, which largely turns on self-reporting ..., has 'demonstrably failed").
} 
foreign military sales in the name of joint defense are justified, do the reciprocal barter and trade aspects (or offsets ${ }^{29}$ ) dilute the moral imperative? ${ }^{30}$

These economic or budgetary issues seem less value laden than the thorny issues associated with arms proliferation, ${ }^{31}$ particularly when the consumer- no matter how well aligned its interests - may be a less stable or, in the worst case, more aggressively hostile regime. As Nancy Hite-Rubin cautions in Chapter 11, arms sales do not exist in a vacuum: "The transfer of major arms into ... politically risky markets creates major security concerns, as well as development concerns." 32

${ }^{29}$ Robert Woodard, Bureau of Indus. \& Sec., Dep'T of Com., OfFSETS In Defense Trade - Frequently ASKED QUESTIONS (2017), https://www.bis.doc.gov/index.php/documents/pdfs/1677-offsets-in-defense-trade-faqsfinal/file; see also Arms Export Control Act, 22 U.S.C. § 2751, et seq.; International Traffic in Arms Regulations, 22 C.F.R. $\S$ 120-130; DFARS Subpart 225.73. See also Daniel Schoeni's thoughtful exposition in Chapter 12 on defense offsets, "a subject that has been presumed guilty without receiving a fair appraisal." Schoeni at _ (1). We find comfort in Schoeni's concession that "the ethical objections [to offsets] made thus far lack force," which "is not to say that ethical [or moral] hazards do not exist," though "what has been written has often been too dismissive." Id. at _ (2). Ultimately, however, the fact that offsets are not "an inherently corrupt practice" does little to dislodge the traditionally perceived yoke of moral hazard. $I d$. at

${ }^{30}$ Although Edward Peartree, in Chapter 3, adds to the chorus suggesting that the U.S. government "is justifiably proud of its reputation as the 'gold standard' of export controls" - a nod to a highly regulated or compliant set of transactions - it is easy to forget that, as a consumer, the U.S. Department of Defense enjoys reduced unit prices for many of its weapon systems because its vendors offer lower unit prices courtesy of the economies of scale associated with global arms sales. Peartree at Yes, Peartree acknowledges that "[s]tates face continuous ethical dilemmas in their decisions whether or not to transfer arms." Id. at But students will likely appreciate the oftunstated but seemingly cynical bargain associated with permitting other states to directly and indirectly subsidize our weapons industry through arms proliferation. "Cost comparisons between [foreign military sales] and [direct commercial sales] are often not possible, ... [but] the FMS sale will always benefit from the economies of scale and experience the U.S. government has with a system." Foreign Military Sales FAQ, DEF. SEC. CoOP. AGENCY, https://www.dsca.mil/foreign-military-sales-faq (last visited Aug. 22, 2021). Yet, at the same time, in Chapter 11, Hite-Rubin starkly warns that "defense contractors face an ethical minefield when they seek lucrative contracts from [less developed countries, yet they represent] ... exactly the market defense contractors must target to stay competitive in a world where defense spending is slowing down in more developed countries." Hite-Rubin at __. It is what it is: "the global defense industry is propelled by demand from institutionally weak, developing nations." $I d$. at _. And kudos to Michael Davis for acknowledging in Chapter 13 that "[m]uch of what the arms industry sells can be stolen, resold, transferred to another by capture, or otherwise "diverted [into the wrong hands]." Davis at

\footnotetext{
${ }^{31}$ Moreover, as Mark Pyman explains in Chapter 10: "Tackling defense corruption is about much more than stopping dodgy commissions on arms sales. Civilians and soldiers die because of corruption in defense, [and] regional security is compromised. ... [Rather, what is needed are] measures to tackle corruption in the defense sector in the context of a 'whole sector' approach, with multiple groups collaborating with and pressuring defense ministries, military forces, defense companies, NATO, NGOs and others." Pyman at Moreover, while Pyman highlights the importance of "the drive and leadership of key individuals" to reform, the same can be said of the setbacks suffered, for example, when the head of Air Force procurement goes to jail or the President disregards and disrespects ethical statutes, regulations, policies, and norms. See generally supra note 27; infra note 49.

${ }^{32}$ Hite-Rubin at ___ (footnote omitted). While we appreciate Michael Davis's optimism, in Chapter 13, that enhanced quality control - for example, safe landmines - serves the public interest and may be less "morally objectionable," we also appreciate his acknowledgement that "every artifact embedded in the technological system we call 'the military' is there to help the military do its job, which is (by definition) to kill, wound, or otherwise disable other human beings on a large scale or destroy property on a large scale, a morally dubious undertaking,
} 
Again, there is no shortage of ethical fodder for research and classroom banter. But do we risk a "whataboutism" response ${ }^{33}$ when we focus on regulating or managing or marginally improving discrete aspects of the defense industry? Is it somehow wrong to do so without instead focusing exclusively on the overarching issue of whether our nation could exist (or even thrive) without a defense industry (or a less massive, expensive, expansive defense industry)?

\title{
3. Assume a Peaceful World...
}

\author{
Imagine there's no countries \\ It isn't hard to do \\ Nothing to kill or die for \\ And no religion, too \\ Imagine all the people \\ Livin' life in peace.... 34
}

One of us vaguely recalls being amused the first time seeing the bumper sticker: It Will Be a Great Day When Our Schools Get All the Money They Need and the Air Force Has to Hold a Bake Sale to Buy a Bomber. ${ }^{35}$ With time and experience in the industry, the powerful clarity of its message grew stronger, and the unflattering things it said about our priorities, our values and, in this context, our ethics still gives cause for reflection. ${ }^{36}$

With special conviction for one of us in particular (as a veteran, and the son of a veteran currently resting in Arlington National Cemetery), we unapologetically affirm our desire to live in a peaceful world. And although the military and the defense industry funded-directly and

especially if the regime directing the military is itself morally dubious." Davis at . To be fair, however, innumerable military institutions (such as the Coast Guard) and missions (such as humanitarian relief) alleviate suffering and avoid loss of life, but the underlying point's validity endures.

${ }^{3}$ See Danielle Kurtzleben, Trump Embraces One of Russia's Favorite Propaganda Tactics - Whataboutism, NPR (Mar. 17, 2017), https://www.npr.org/2017/03/17/520435073/trump-embraces-one-of-russias-favorite-propagandatactics-whataboutism (observing, "One big reason whataboutism is so attractive: it's a simple way to shrug off criticism or even responsibility for any wrongdoings.”).

${ }^{34}$ John Lennon, Imagine, on IMAGINE (Apple Records1971)

${ }^{35}$ Popular bumper sticker and poster, created between 1965 and 1980, attributed to Women's International League for Peace and Freedom. It Will Be a Great Day When Our Schools Get All the Money They Need and the Air Force Has to Hold a Bake Sale to Buy a Bomber, LIBR. OF CONG., https://www.loc.gov/resource/ds.13124 (last visited Jan. 9, 2022).

${ }^{36}$ Paul Krugman, The Bogus Bashing of Build Back Better, N.Y. TIMES (Dec. 13, 2021), https://www.nytimes.com/2021/12/13/opinion/build-back-better.html (putting in context that “the bill's $\$ 1.75$ trillion price tag is, on the surface, a lot of money. But that's spending over 10 years, which means that annual outlays would be far smaller than the $\$ 1.9$ trillion rescue plan passed this year or, for that matter, the $\$ 768$ billion annual defense bill the House passed [without flinching] last week."). 
indirectly - much of one of our lives, ${ }^{37}$ we would still prefer to live in a state that did not spend such staggering sums of money, and far too much of its available capital, on the defense industry.

Even Switzerland, which is traditionally committed to (armed) neutrality and de facto protected by NATO member states, nevertheless invests in a large military where every male must serve as a reservist (and women may choose to serve). Across the pond, Costa Rica, often referred to as the Switzerland of Central America, does not maintain a standing military, but relies upon its police forces for what other states consider traditional or conventional defense. Moreover, while most states without armed forces are relatively small, with island states featuring prominently, many enjoy protection afforded by other states through formal and informal agreements.

Unfortunately, that peaceful world of bards and bumper stickers, desired by pacifists, and, yes, soldiers, remains beyond our grasp. Nor do we expect to see the United States transformed to such a state in either of our lifetimes. The defense industry - and, for that matter, the military-does consume staggering sums of resources and does play a disproportionate role in the public policy space. We therefore cannot afford to focus solely on broader existential hypotheticals that might, if real, render this book's nuanced discussions irrelevant. At least at present, they are not real, so we have no choice but to walk the labyrinthian path and pay attention to the ethical complexities and peculiarities of the defense industry.

\section{If You're Gonna Fight, Win}

In the spring of 1980 , for the first time, one of us stepped out the door of a perfectly good airplane in flight without a care for the seemingly mundane but oh-so-critical topic of "quality assurance" in defense acquisition. ${ }^{38}$ That moment resonated years later when reading about defense contracts for "man-rated items," so designated "because the lives of people are at risk in an emergency in the event of a failure of that system." ${ }^{39}$ Exiting the relative safety of an inflight aircraft, a soldier enjoys neither the luxury nor the opportunity to formally express her fervent hope, as an "end user," that the contracting officer ${ }^{40}$ was not satisfied with (an otherwise impressive) 95 percent, or even 99 percent, success rate in parachute testing.

\footnotetext{
${ }^{37}$ Schooner's father served on active duty in the military until Schooner was in college, which he attended on a full Army ROTC Scholarship. Even before college, he graduated from a Department of Defense high school in Europe, where he actively participated in Junior ROTC. His first (non-temporary) full-time job was as an officer in the U.S. Army, and he served in the Army Reserves for many years after leaving active duty. Much of his legal practice and, eventually, scholarship was dominated by defense contracting or defense acquisition. As one might say, with apologies to Minnie Minoso, Roberto Clemente, Sammy Sosa, and, of course, Chico Escuela, "the Army was very, very good to him.”

${ }^{38}$ See, e.g., FAR Part 46, 48 C.F.R. 46; JOHN CIBINIC, JR., JAMES F. NAGLE \& RALPH C. NASH, JR., ADMINISTRATION OF GOVERNMENT CONTRACTS 697-790 (5th ed. 2016).

${ }^{39}$ Appeal of Astro Dynamics, Inc., ASBCA No. 28381, 88-3 BCA $₫$ 20,832 (1988).

${ }^{40}$ The contracting officer, a creature of statute and regulation, is the appointed official with authority to (among other things) bind the government in contract. See generally FAR 1.102-3; FAR Subpart 1.6. See also FAR 1.602-1
} 
It is easy to forget about the end user - the consumer of what the defense acquisition system delivers to the warfighter - at the proverbial tip of the spear. But pause for a moment and remember that, for the parent or spouse or relative of such an end user, the defense industry looks quite different; indeed, the concept of "customer satisfaction" takes on a whole new meaning. Consider, then, the juxtaposition in which the Iraqi population, and, over time, the American public, came to revile the name Blackwater, while innumerable State Department officials, Members of Congress, and others returned home to their loved ones thankful for and appreciative of Blackwater's (admittedly heavy-handed and risk-averse) protection. ${ }^{41}$ All of which brings to mind the sublime proverb: Until the Lion writes history, the tale of the hunt will always glorify the hunter. ${ }^{42}$

So long as we maintain a military, and until we lay down our arms, this perspective- the soldier's perspective - matters. In government contracting policy discussions, we like to emphasize the "end user," and defense acquisition experts refer to "the warfighter" as the ultimate customer. Is that perspective the highest ethical imperative? In Chapter 5, General Ayres, Kevin Govern, and Michael W. Meier suggest that "no one longs for peace like the experienced soldier. But, when war comes, no one longs for superior technology and weapons like a soldier." 43 Indeed, they go so far as to posit that the Laws of Armed Conflict (LOAC) do "not require a fair fight, nor [do they] prohibit the use of superior offensive or protective weaponry." ${ }^{44}$ Is military superiority, in and of itself, a worthy ethical pursuit? For an armed combatant, or the relative of an armed combatant, that likely sounds like music to anxious ears. Until our military force becomes fully automated, ${ }^{45}$ we cannot ignore this perspective.

("Contracting officers have authority to enter into, administer, or terminate contracts and make related determinations and findings.").

41 "I think on balance we felt that ... the protective security operation has been highly effective." Special Briefing with Patrick F. Kennedy, Ambassador, Dept' of State, on the Report of the Secretary of State's Panel on Personal Protective Services in Iraq (Oct. 23, 2007), https://2001-2009.state.gov/r/pa/prs/ps/2007/oct/94019.htm.

${ }^{42}$ See, e.g., Annalisa Quinn, Chinua Achebe and the Bravery of Lions, NPR (Mar. 23, 2013), https://www.npr.org/sections/thetwo-way/2013/03/22/175046327/chinua-achebe-and-the-bravery-of-lions. In more concrete terms, "“[s]ilo mentality” is a widely occurring phenomenon wherein a profession . . . or an organization itself is so focused on their priorities or their expertise that they neglect or fail to perceive how those priorities affect or are affected by other professions, divisions ..., or others in their industry." Patricia Werhane at

${ }^{43}$ Ayres, Govern \& Meier at (32).

${ }^{44} I d$. at _ (11). We concede being far less sanguine with the more extreme position staked out by Duncan Macintosh in Chapter 2: "It is the measure of the goodness of a culture how good its weapons are - the better the weapons, the better the culture." Macintosh at ethical bridge too far.

${ }^{45}$ In Chapter 8, Blake Hereth and Nicholas G. Evans draw attention to the exploding potential and promise (and potential ethical problems) of artificial intelligence (AI) and the future of, among other things, lethal autonomous weapon systems (LAWS). Hereth \& Evans at _ (1). During the prior generation, advancements in unmanned vehicles, remote piloting, and, increasingly, robotics drastically altered and animated a battlefield far different from prior experience. See generally Steven L. Schooner \& Nathaniel Castellano, Dawn Of the Intercontinental Sniper: The Drone's Cascading Contribution to the Modern Battlefield's Complexity, 8 J. NAT'L SEC. L. \& POL'Y 321 


\section{Not Your Grandparents' (Nor Eisenhower's) Defense Industry}

One of this volume's great contributions is the organized fashion in which it discretely analyzes many of the pathologies spawned by our long-standing military-industrial complex. ${ }^{46}$ Yes, problems remain. But we have also seen real progress, ranging from industry cognizance and commitment to the evolution of compliance regimes, adoption of codes of conduct, and proliferation of voluntary disclosures systems..$^{47}$ At the same time, some of those problems simply are not as problematic as they might seem, and others cannot be laid entirely at the feet of the defense industry. Again, it is complicated.

As frustrated as many of us have become with over-reliance on the military-industrial complex trope ${ }^{48}$ it serves as a helpful reminder that many of the ethical issues that arise from the context - kinetic solutions to social problems, staggering sums of money spent in the grey area where ends justify the means, etc. - do not conform to intellectually lazy categories. Not all public servants are inherently good, nor are all contractor personnel greedy profiteers and pigs at

(2016) (reviewing Richard WhitTle, PREDATOR: THE SECRET ORIGINS OF THE DRONE REVOLUTION (2014)). Looking ahead, the range of potential issues is bounded only by our imaginations. See, e.g., Erico Guizzo, How Boston Dynamics Is Redefining Robot Agility, IEEE SPECTRUM (Nov. 27, 2019), https://spectrum.ieee.org/howboston-dynamics-is-redefining-robot-agility. On a lighter (but nonetheless eye-opening) note, see Boston Dynamics, Do You Love Me?, YOUTUBE (Dec. 29, 2020), https://www.youtube.com/watch?v=fn3KWM1kuAw.

${ }^{46}$ Supra note 13. Legislation, regulation, compliance regimes, self-regulation, professionalization, transparency, and innumerable other inputs have led us to where we are today, where defense acquisition is dominated by massive, sophisticated firms, supplemented by an ever-changing cast of new entrants and innovators. Nonetheless, given the stakes, it is "scholarly neglect" to not contemplate these issues more frequently, and "this book aims to contribute to a field of study whose significance has been underappreciated." Schoeni \& Vestner at

${ }^{47}$ See infra text accompany notes 54-62. See also supra note 18.

48 "[T] he "military-industrial complex" is often the bogeyman of journalistic investigations and conspiracy theories." SAPOLSKY, ET AL., supra note 10, at 4. 
the trough. ${ }^{49}$ From the end of the twentieth century and into the post-millennial outsourcing era, ${ }^{50}$ what happens to our preconceptions of military culture and norms of behavior ${ }^{51}$ when the U.S. military cannot see, move, fight, communicate, or sustain itself without a fully integrated contractor presence ? $^{52}$ Yet as exhaustive and as thought-provoking as this volume proves, it

\begin{abstract}
${ }^{49}$ In looking back over the last few decades, even taking into account Blackwater's notorious 2007 Nisour Square massacre, it is impossible to tilt the scales sufficiently to conclude, let alone empirically demonstrate, that private sector behavior in the government contracting marketplace has been in any way less ethical, virtuous, or compliant than that of government officials, including the (former) President. See generally Laurel Wamsely, Shock and Dismay After Trump Pardons Blackwater Guards Who Killed 14 Iraqi Civilians, NPR (Dec. 23, 2020), https://www.npr.org/2020/12/23/949679837/shock-and-dismay-after-trump-pardons-blackwater-guards-who-killed14-iraqi-civil; Falih Hassan \& Jane Arraf, Blackwater's Bullets Scarred Iraqis. Trump's Pardon Renewed the Pain, N.Y. Times (Dec. 23, 2020), https://www.nytimes.com/2020/12/23/world/middleeast/blackwater-trump-pardon.html ("For some survivors of the attack, President Trump's pardon of the Blackwater contractors was a bitter reminder of what Iraqis have always viewed as a lack of concern over Iraqi lives."). Consider, among other high-profile scandals, that while "Fat Leonard" animated the most pervasive post-millennial scandal, hundreds of military officers and personnel put the Navy's Seventh Fleet's culture on trial, top to bottom. Craig Whitlock \& Kevin Uhrmacher, Prostitutes, Vacations and Cash: The Navy Officials "Fat Leonard" Took Down, WASH. POST (Sept. 20, 2018), https://www.washingtonpost.com/graphics/investigations/seducing-the-seventh-fleet/. Before that, the Darlene Druyun saga saw both the Air Force's senior procurement official and the Chief Financial Officer of one of the nation's largest companies (and household names), Boeing, Michael M. Sears, spend time in the federal penitentiary. John A. Tirpak, Druyun's Downfall, AIR ForCE MAG.: WASH. WATCH (Nov. 1, 2004), https://www.airforcemag.com/article/1104watch.
\end{abstract}

${ }^{50}$ Even at the peak of the U.S. involvement in Iraq and Afghanistan, where an increasingly blended battlespace saw contractors performing tasks previously considered the domain of uniformed personnel, or inherently government (or military) functions, the discussion of these difficult issues was short-lived. See Rachel Augustine Potter, Macro Outsourcing: Evaluating Government Reliance on the Private Sector, J. POL. (forthcoming),

https://ssrn.com/abstract=3907539 ("Today, state governments routinely offload . . government functions to the private sector. This trend is replicated at the federal level, where contractors help fight wars, run prisons, collect taxes, write regulations, render benefit decisions, and shape policy."); see also ALLISON STANGER, ONE NATION Under Contract: The OUtSOURCING OF AMERICAN POWER AND THE Future OF Foreign POLICY (2011); PAUl C. Light, THE GOVERnMENT-INDUSTRIAL COMPLEX: THE TRUE SizE OF THE FEDERAL GOVERNMENT, 1984-2018 (2019); Steven L. Schooner, The Well-Reasoned Case for Reversing the Outsourcing Trend: A Review Essay of Jon Michaels' CONSTITUTIONAL COUP: PRIVATIZATION's THREAT TO THE AMERICAN REPUBlic, 59 GOV'T CONTRACTOR I 319 (2017); Rebecca R. Vernon, Battlefield Contractors: Facing Tough Issues, 33 PUB. ConT. L.J. 369 (2004); Michael Davis, Ruck Up: An Introduction to the Legal Issues Associated with Civilian Contractors on the Battlefield, 29 PuB. ConT. L.J. 233 (2000); Steven L. Schooner \& Daniel S. Greenspahn, Too Dependent on Contractors? Minimum Standards for Responsible Governance, 6 J. ConT. MGMT. 9 (2008); Steven L. Schooner, Contractor Atrocities at Abu Ghraib: Compromised Accountability in a Streamlined, Outsourced Government, 16 Stan. L. \& Pol'y ReV. 549 (2005); SeAn McFate, The Modern Mercenary: Private ARMies and What They MEAN FOR WORLD ORDER (2015).

${ }^{51}$ For a fascinating historical perspective on how far we have come in this regard, see, for example, CHARLES EDWARD White, THE ENLIGHTENED SOlDIER: SCHARNHORST AND THE MilitARISCHE GESELlSCHAFT IN BERLIN, 1801-1805 (1989). White's historical vignette chronicles the transition from a feudal (or royal) monopoly over the arms-bearing "arts" to the more modern profession of citizen soldiers, selected on merit, educated (not only in combat-related skills, but also in critical thinking and problem solving), led (in battle) by a meritocracy rather than the worst byproduct of a monarchy: ever-diminishing, arrogant, insular, ill-prepared, and closed-minded bloodlines. See also infra note 85.

${ }^{52}$ See SAPOLSKY, ET AL. supra note 10 at 8-9, 298-99 ("The question policy-makers need to ask is: What must be retained as governmental or public, in the acquisition of weapons, training of soldiers, and the conduct of war? What tasks must the government perform directly to ensure its monopoly on the legitimate use of force ... ? ... The 
merely scratches the surface. But like any good academic exercise, ${ }^{53}$ it makes us confront that which we fail to think about, that which we take for granted, and that which we must not ignore.

Problems remain, scandals occur, and it is perfectly reasonable to hold the defense industry, which, as Leo Mackay reminds in his Foreword, "builds instruments of destruction and lethality[, used] to maintain [the public's] way of life, even [its] very existence," 54 to a higher standard than the general commercial marketplace. ${ }^{55}$ Fortunately, as a number of the chapters in this book explain, the defense acquisition landscape is far more regulated, responsible, transparent, and compliant than when Eisenhower left the White House. On the one hand, while all may not share Mackay's optimism that "we have come a long way regarding the most salient ethical challenges in the defense industry," it does appear that "national laws and industrial standards are rising and becoming mainstream," 56 and that trend is a source of optimism. The

public and the private blend in providing America's defense. Private firms develop America's most advanced weapons and deploy personnel along with the troops to help them fight more effectively."); see also GOVERNMENT By CONTRACT: OUTSOURCING AND AMERICAN DEMOCRACY (Jody Freemen \& Martha Minow eds., 2009); supra note 18 .

${ }^{53}$ In Chapter 4, Richard Painter's four-part thought experiment offers an excellent opportunity to unpack some of these issues. Painter at __ $(2-5,11-14)$. In addition to the broad legal principles addressed in Painter's chapter, students (or for that matter, scholars) might be asked to read, compare, and contrast the coverage and guidance found in some of the major defense contractors' (publicly disclosed) codes of conduct to see if they would inform, guide, or constrain the contractors' (or their C-suites' or directors') actions. For example, the world's largest defense contractor, Lockheed Martin, publishes (in more than a dozen languages) its code of ethics and business conduct, which "details the high expectations we set for employee behavior, from our commitment to good citizenship to our zero-tolerance policy on corruption, serving as the most basic building block for future success." Code of Conduct, LOCKHEED MARTIN, https://www.lockheedmartin.com/en-us/who-we-are/ethics/code-of-ethics.html (last visited Jan. 9, 2022).

${ }^{54}$ Mackay at _.. In Chapter 3, Edward Peartree reminds us that much of the weapons market involves international arms trafficking, of the legalized sort, which in the U.S. is sanctioned under the Foreign Military Sales (FMS) regime and cabined by the International Trafficking in Arms Regulations (ITAR). See Peartree at _ ("If you are a defense firm selling your products pursuant to FMS, all aspects of the sale are subject to a legally binding 'letter of offer and acceptance' [LOA] between the United States and the foreign government recipient."). See generally Directorate of Defense Trade Controls, U.S. DEP'T OF STATE, https://www.pmddtc.state.gov/ddtc public (last visited Jan. 9, 2022); AECA, 22 U.S.C. § 2778; ITAR, 22 C.F.R. 120-130.

${ }^{55}$ Again, in Chapter 4, Richard Painter poses a thorny policy problem, juxtaposing a loyalty aspiration for profitseeking defense contractors against a longstanding congressional bias in favor of maximizing competition. Although many readers might instinctively agree that "companies should only be allowed to compete for large-scale U.S. Government defense contracts if they certify, in articles of incorporation or by-laws or elsewhere, and disclose to shareholders, that a primary purpose of the enterprise is to strengthen the national security," Painter at _ (18), that approach runs contrary to more than two decades of congressional policy, nay, insistence, that the defense acquisition marketplace not be limited to conventional defense firms. See, e.g., FAR 12.101, 48 C.F.R. 12.101 (mandating that agencies "[a]cquire commercial products, commercial services, or nondevelopmental items when they are available to meet the needs of the agency"); see also FAR 2.101, 48 C.F.R. 2.101 (defining "commercial product" in a manner that suggests a commercial product or service "is of a type customarily used by the general public or by nongovernmental entities for purposes other than governmental purposes" (emphasis added)).

${ }^{56}$ Mackay at __. Credit should go to Norman Ralph Augustine, who served, among other roles, as Under Secretary of the U.S. Army and later as chairman and CEO of the Lockheed Martin Corporation, for his leadership on these issues. See Richard G. Weingardt, Norman Ralph Augustine, 9 LEADERSHIP \& MGMT. ENG'G 149 (2009). But see William D. Hartung, Saint Augustine's Rules: Norman Augustine and the Future of the American Defense, 13 
industry has taken massive strides, prodded and propelled by a broad range of inputs, including but by no means limited to:

- conventional oversight and law enforcement organization, such as, in the U.S., Congress, GAO, DoJ, the IG community, and the Interagency Suspension and Debarment Committee (ISDC); ${ }^{57}$

- governmental institutions abroad, such as the Organization for Economic Cooperation and Development (OECD) ${ }^{58}$ and the Geneva Centre for Security Sector Governance (DCAF); ${ }^{59}$

- civil society, including Transparency International (TI); ${ }^{60}$ and

- the industry itself, led by, among others, the Defense Industry Initiative on Business Ethics and Conduct (DII), ${ }^{61}$ the International Forum on Business Ethics and Conduct (IFBEC), ${ }^{62}$ and the International Stability Operations Association (ISOA). ${ }^{63}$

Failure to acknowledge the significance of the change, and the dramatically improved

WORLD POL'Y J. 65 (1996) ("It is hard to fault Augustine for driving the best possible bargain for his company, but one has to question the process by which he achieved his goal.").

${ }^{57}$ See generally Interagency Suspension and Debarment Committee (ISDC), ACQUISITION.GOV, https://www.acquisition.gov/isdc-home (last visited Jan. 9, 2022); Exec. Order No. 12,549, 51 Fed. Reg. 6370 (Feb. $18,1986)$.

${ }^{58}$ Anti-Corruption \& Integrity Hub, OECD, https://www.oecd.org/corruption-integrity (last visited Aug. 22, 2021).

${ }^{59}$ What is DCAF, GENEVA CTR. FOR SEC. SECTOR GOVERNANCE, https://dcaf.ch/about-us (last visited Jan. 9, 2022); see also Private Military and Security Companies: Implementation of Montreux Document, INT'L COMM. OF THE RED CROSS (Dec. 16, 2014), https://www.icrc.org/en/document/private-military-and-security-companiesimplementation-montreux-document.

${ }^{60}$ Transparency International's priorities include defense and security, see What Is Defence and Security and Corruption?, TRANSPARENCY INT'L, https://www.transparency.org/en/our-priorities/defence-and-security (last visited Aug. 22, 2021), and public procurement, see Public Procurement, TRANSPARENCY INT'L, https://www.transparency.org/en/our-priorities/public-procurement (last visited Aug. 22, 2021).

${ }^{61}$ Def. Indus. Initiative on Bus. Ethics \& Conduct, https://www.dii.org (last visited Aug. 22, 2021).

${ }^{62}$ About, INT'L ForUm On BUS. ETHICS \& CONDUCT FOR THE AEROSPACE \& DeF. INDUS., https://ifbec.info/about (last visited Aug. 22, 2021).

${ }^{63}$ INT'L STABILITY OPERATIONS ASs'N, https://stability-operations.org (last visited Aug. 22, 2021). "ISOA was founded ... as the International Peace Operations Association [IPOA].”Id. at https://stability-

operations.org/page/History. In particular, see ISOA's "Code of Conduct, which represents a constructive effort towards better regulating private sector operations in conflict and post-conflict environments and disaster relief. It reflects our belief that high standards will both benefit the industry and serve the greater causes of peace, development, and human security." Id. at https://stability-operations.org/page/Code. 
state of affairs, is as inaccurate as it is unfair. Of course, that does not suggest our work is complete, and plenty of room for improvement and growth remains. To that end, it is unsurprising that, in a high-stakes market involving hundreds of billions of dollars flowing through tens of millions of contractual agreements, new scandals constantly reveal themselves. Nor should it surprise us that the oversight community publishes a steady stream of critiques, that contractors over-promise or find themselves stretched too thin, that individuals behave badly, or that mistakes are made.

History reminds us that it is easy (and popular) to criticize the defense industry and, more broadly, the military-industrial complex. If you read GAO's seemingly never-ending tsunami of reports on the defense industry, ${ }^{64}$ you could be forgiven for concluding that the Department of Defense is adrift, defense acquisition is in tatters, and no one knows where far too much of the money has gone. To a hammer, everything is a nail. And while oversight is necessary, it does not tell the whole story. Not surprisingly, academic study and closer examination breeds familiarity with complex issues that may explain certain pathologies, but nonetheless fail to illuminate a path to better practices or outcomes. ${ }^{65}$ Patricia Werhane, in Chapter 16, explains:

When there is wrongdoing in our society, . . . an individual, group of individuals, or an organization is or are often singled out for blame. . . . But sometimes, at least, these misdeeds occur not because of deliberate malfeasance, but rather because of complex collective action that produced these negative outcomes. ${ }^{66}$

It is also intellectually lazy to focus criticism exclusively on "the defense industry," or the private sector's (or, in other words, defense contractors') failures and shortcomings when: (1) Congress exercises complete control over the defense budget, (2) individual members of Congress aggressively endeavor to maximize defense spending that benefits their constituents, (3) contractors cannot sell what governments will not buy, and (4) government authorization (and, typically, facilitation) is a prerequisite for selling their wares abroad. Arguably no better recent anecdote exposes the absurdity of congressional defense priorities than the military's inability to retire the A-10 from service. ${ }^{67}$

\footnotetext{
${ }^{64}$ For a representative sample, see the annual High Risk List, U.S. Gov'T ACCOUNTABILITY OFF., https://www.gao.gov/high-risk-list (last visited Oct. 7, 2021) (heavily populated with defense-related topics) or visit the GAO's topical pages focused on, inter alia, National Defense, https://www.gao.gov/topics/national-defense (last visited Oct. 7, 2021), Auditing and Financial Management, https://www.gao.gov/topics/auditing-and-financialmanagement (last visited Oct. 7, 2021), Budgeting and Spending, https:/www.gao.gov/topics/budget-and-spending (last visited Oct. 7, 2021), or Veterans, https://www.gao.gov/topics/veterans (last visited Oct. 7, 2021).

${ }^{65}$ Discussing the life cycle of a major weapon system, and the various (typically polarized) perceptions of their history and utility, can be understood by analogy to the parable of the blind men and the elephant, commonly attributed to the ancient Indian subcontinent. As a single anecdote, see Steven L. Schooner \& Nathaniel E. Castellano, Review Essay: Reading The DreAm Machine: THE Untold StORY OF THE Notorious V-22 OspreY, by Richard Whittle, in Light of the Defense Acquisition Performance Study, 43 PUB. ConT. L.J. 391 (2014).

${ }^{66}$ Werhane at
} 
For more than a decade, Wisconsin Senator William Proxmire highlighted government waste with a monthly "Golden Fleece" award. ${ }^{68}$ Although spread across government instrumentalities, the defense industry was criticized for investing (a relatively modest sum) in a study to determine whether umbrellas should be carried by uniformed personnel. ${ }^{69}$ But history reminds us that one critic's waste is another's passion, priority, policy, pet project, or, well, "pork." For example, what is the economic utility of the federal government maintaining multiple undergraduate institutions to produce entry-level officers? How can the federal government tolerate its military academies loosening their academic standards and diverting (allegedly scarce) resources to groom potential athletes for the purpose of competing against institutions of higher education funded by individual states or the private sector? ${ }^{70}$ From either an ethical or a fiscal law standpoint, ${ }^{71}$ it is a long, tortured path from publicly funding competitive collegiate sports to the social imperatives associated with the nation's safety and security.

\footnotetext{
${ }^{67}$ See Mike Stone, The Warthog and the Senator: The Politics of Retiring a Warplane, ReUTERS (July 16, 2021), https://www.reuters.com/world/us/warthog-senator-politics-retiring-warplane-2021-07-16 ("The U.S. Air Force is desperate to get rid of some of its fleet of expensive, slow and outdated A-10 Warthog airplanes, but politicians have blocked the move, aiming to keep the local dollars flowing."); see also Derek O'Malley \& Andrew Hill, Close Air Support in 2030: Moving Beyond the A-10/F-35 Debate, WAR ON THE ROCKS (May 28, 2015), https://warontherocks.com/2015/05/the-a-10-the-f-35-and-the-future-of-close-air-support-part-ii (elaborating upon the misplaced priorities in the debate to retire the A-10 and quoting former Air Force Chief of Staff-and former A10 pilot - General Mark Welsh: "I find myself arguing to get rid of things that I don't want to get rid of to pay a bill we've been handed. And the people [that] tell me I can't give up anything to pay it, are the people who gave us the bill. It's a strange situation.").

${ }^{68}$ See, e.g., Reestablish the Golden Fleece Award, 161 Cong. Rec. H3397 (daily ed. May 20, 2015) (statement of Rep. Hill), https://www.congress.gov/congressional-record/2015/05/20/house-section/article/H3397-2.
}

${ }^{69}$ The idea that, for generations, it was considered improper for uniformed personnel to carry umbrellas flummoxes us to this day. Ben Kesling, Semper Dry: Now Marines Can Carry Umbrellas, Setting Off Stormy Debate, WaLl St. J. (Nov. 11, 2019), https://www.wsj.com/articles/semper-dry-now-marines-can-carry-umbrellas-setting-off-stormydebate-11573494284 (noting that "[f]emale Marines were given permission to use umbrellas back in $1972 \ldots$. . [while t]he Army, Navy and Air Force have long authorized umbrellas for use by both sexes").

${ }^{70}$ Billy Witz, How a Military Prep School Helped Army Improve in Football, N.Y. TIMES (Sept. 22, 2019), https://www.nytimes.com/2019/09/09/sports/army-prep-school.html. The service academies originally formed prep schools to create opportunities for enlisted soldiers to become officers and to increase diversity; today they also use prep schools to be more competitive in Division I sports, primarily football and basketball, instituting a de facto redshirt year during which these athletes to get bigger, stronger, and faster. And before you ask how much the academies lower their academic standards, assume you don't want to know. "The mean SAT score for this year's class at the prep school was about 130 points [or just over 10 percent] lower than that of the cadets who were admitted directly to the academy.... While Army won't be admitting anyone with a 2.0 grade-point average or an 800 SAT score, ... the admissions committee ha[s] been encouraged to take a more inclusive view of an applicant's file, including community service, leadership, character and athletic traits." Id.

${ }^{71}$ One of the fundamental statutes dealing with the use of appropriated funds is 31 U.S.C. $\S 1301$ (a), also known as the purpose statute: "Appropriations shall be applied only to the objects for which the appropriations were made except as otherwise provided by law." U.S. GOV’T ACCOUNTABILITY OFF., GAO-17-797SP, Availability of Appropriations: Purpose, in PRINCIPLES OF FEDERAL APPROPRIATIONS LAW 3-1, 3-9 (4th ed. 2017) (quoting 31 U.S.C. § 1301(a)), https://www.gao.gov/assets/2019-11/687162.pdf. 
At the same time, history reminds us that, although anecdotes of wasteful spending are a given and counting defense scandals is good sport, particularly in light of the military's massive scale and insatiable needs and desires, anecdotes can be deceiving. ${ }^{72}$ Just as the familiar triad of "fraud, waste, and abuse" often clumps together different pathologies and proposed remedies, over-emphasis on anecdotes of defense industry shortcomings potentially paints an inaccurate picture and distract us from fundamental, often intractable, issues. ${ }^{73}$

\title{
6. The Forest, ... And The Trees
}

\author{
I've been living to see you \\ Dying to see you \\ But it shouldn't be like this \\ This was unexpected \\ What do I do now? \\ Could we start again, please? \\ I've been very hopeful, so far \\ Now, for the first time \\ I think we're going wrong \\ Hurry up and tell me \\ This is just a dream \\ Or could we start again, please? ${ }^{74}$
}

In retrospect, we may fairly be criticized, in examining defense industry ethics, for focusing on the failings and tension points - or what we might consider implementation pathologies - that arise within a large, complicated military-industrial complex. As we isolate discrete issues, problems, and quandaries, our various topical tasks permit us to take for granted that the nation needs a large military-industrial complex. Although we acknowledge the harsh reality that we do not live in a peaceful world, we do not, as noted above, address why the United States should (or should not) be our allies', the region's, or even (at its most aspirational) democracy's protector and enforcer. We welcome that debate.

\footnotetext{
${ }^{72}$ And, of course, historical events can generate multiple storylines and parables. For many, familiarity with the WW II sinking of the U.S.S. Indianapolis (which delivered one of the atomic bombs' components before becoming the last American ship sunk during the War) is limited to the iconic galley scene from the movie JAWS (Universal 1975), available at https://www.youtube.com/watch? $\mathrm{v}=\mathrm{u} 9 \mathrm{~S} 41 \mathrm{Kplsbs}$. When the wreck was discovered in 2017 , 18,000 feet below the surface, many of us learned, for the first time, that Navy Captain Charles B. McVay III, who had been court-martialed for the loss of his ship in a high-profile, but deeply flawed proceeding, was exonerated after he committed suicide. See DOUG STANTON, IN HARM's WAY (2001) for a powerful case study in diffusion of responsibility, scapegoating, and a failure of military justice.

${ }^{73}$ See, e.g., supra note 21.

${ }^{74}$ Andrew Lloyd WebBer \& Tim Rice, Could We Start Again Please?, on Jesus Christ SuPERSTAR (MCA Records 1973)
} 
But even that issue is framed too narrowly. How carefully do we endeavor to quantify the externalities, effects, ${ }^{75}$ or opportunity costs of our massive military-industrial complex and, more broadly, our martial instincts, culture, and self-image? Maybe the most pernicious aspect of the centrality of a high-profile military extends far beyond the defense industry. For many nonAmericans, one of the defining features of what it means to be an American is the pervasive and destructive gun culture. ${ }^{76}$ The American Public Health Association (APHA) reminds us that gun violence is a "leading cause of premature death" in the United States: "Each year, more than 39,000 people in the United States die as a result of gun violence, and tens of thousands more suffer non-fatal gun injuries." "77 While APHA advocates that "[g]un violence is not inevitable," there seems minimal political will to address "[t]he burden of gun violence in the United States[, which] vastly outpaces that in comparable countries.",78

Baby Boomers grew up inspired by the technological advances spawned from NASA's pursuit of a moon landing: from freeze-dried food to fire-retardant suits and integrated circuits. Today, as we look outward towards space, as Brian Green explains in Chapter 6, it is not only the next frontier, but it also raises a raft of additional, complex questions. ${ }^{79}$ Meanwhile, many point to the militarization of police forces as the natural evolution of the defense industry's pursuit of broader markets. ${ }^{80}$ These are not idle concerns. And if you are worried about the state

\footnotetext{
${ }^{75}$ We encourage use of the term "effects" instead of "negative externalities." See generally KATE RAWORTH, DOUGHNUT ECONOMICS 123 (2017). Let us "drop the economist's beloved notion of 'externalities,' those incidental effects felt by people who were not involved in the transaction that produced them.... Due to the scale and interconnectedness of the global economy, many economic effects that were treated as 'externalities' in the twentieth-century theory have turned into defining social and ecological crises in the twenty-first century." Id.

76 " $[\mathrm{I}] \mathrm{t}$ is no coincidence that . . the U.S. . . . is also a gun culture. For what is true in the large in this case is also true in the manner of fractals right down to the small. . . . [T] he cost is 30,000 lives per year in gun violence. But the cost buys you absolute immunity to invasion from without, and from certain kinds of tyranny within." MacIntosh at

${ }^{77}$ Gun Violence Is a Public Health Crisis, Am. PUB. HeAlth Ass'N, https://www.apha.org//media/Files/PDF/factsheets/200221_Gun_Violence_Fact_Sheet.ashx (last visited Jan. 9, 2022).
}

${ }^{78} I d$. How much of that core value derives from a zealous extrapolation of a 1791 Constitutional amendment asserting that "[a] well regulated Militia ... [is] necessary to the security of a free State"? U.S. CONST. amend. II. It is beyond the scope of this exercise to attempt to unpack how, in good faith, or through principles of interpretation, the first thirteen words in a twenty-seven-word sentence can be so easily, broadly, and vociferously ignored.

${ }^{79}$ As "the exploration and use of the space domain have grown . . , new threats have emerged that require ever more vigilant, well-equipped, and ready military forces to defend the vital space capabilities of the United States and her allies." Green at __. It seems axiomatic that "[a]s the barriers to entry for having a military presence in space have lowered over time and more countries therefore enter this domain, a policy of self-restraint may not serve to resolve all ethical dilemmas that are international in nature." Id. at

80 " [T] $]$ he idea is the Pentagon bought this stuff originally for the military, doesn't need it anymore and can give it to local police departments." David Brancaccio, Rose Conlon \& Candace Manriquez Wrenn, How Police Departments Got Billions of Dollars of Tactical Military Equipment, MARKETPLACE (June 12, 2020), https://www.marketplace.org/2020/06/12/police-departments-1033-military-equipment-weapons; see also Michael Leo Owens, Tom Clark \& Adam Glynn, Where Do Police Departments Get Their Military-Style Gear? Here's What We Don't Know, WASH. Post (July 20, 2020), https:/www.washingtonpost.com/politics/2020/07/20/where-dopolice-departments-get-their-military-style-gear-heres-what-we-dont-know; 1033 Program FAQs, DEF. LOGISTICS 
of the planet that your children and their children will inherit and inhabit, it is disheartening that, beyond the public purview, ${ }^{81}$ the U.S. military consumes more fossil fuels than any other institution in the world. ${ }^{82}$ So be sure to add the climate crisis ${ }^{83}$ to the list of ills exacerbated by our massive military expenditures and activities.

Acknowledging these broader issues and incorporating them into the debates of defense industry ethics requires us to step back and remember to notice both the forest and the trees. As Patricia Werhane reminds us in Chapter 16: "the process of stepping back, which conscientious individuals often engage in — challenging standard operating procedures, ingrained habits, and rote decision processes - is also possible in organizations. This sort of thinking entails moral imagination and moral courage." 84

Are we a moral state? One common refrain of the coronavirus pandemic is that we are a toxic (and sadly mean-spirited) collection of profoundly selfish individuals, lacking the goodwill that binds together healthy communities. ${ }^{85}$ Are we capable of moral action, of acting in our own,

AGENCY, https://www.dla.mil/DispositionServices/Offers/Reutilization/LawEnforcement/ProgramFAQs.aspx (last visited Aug. 22, 2021) (explaining that the 1997 National Defense Authorization Act "granted permanent authority to the Secretary of Defense to transfer defense material to federal, state and local law enforcement agencies").

${ }^{81} \mathrm{We}$ consider it inane that military greenhouse gas emissions continue to be exempted from reporting and national commitments following COP26. See, e.g., Tom Ambrose, World's Militaries Avoiding Scrutiny over Emissions, Scientists Say, GuARDIAN (Nov. 11, 2021), https://www.theguardian.com/environment/2021/nov/11/worldsmilitaries-avoiding-scrutiny-over-emissions ("Armed forces are among the biggest polluters on the planet but are avoiding scrutiny because countries do not have to include their emissions in their targets .... The world's militaries ... are estimated to create $6 \%$ of all global emissions, according to Scientists for Global Responsibility (SGR). COP26, held in Glasgow from October 31 through November 13, 2021, refers to the 26th conference of the parties (COP) to the United Nations Framework Convention on Climate Change (UNFCCC). See generally Glasgow Climate Change Conference, U.N. ClimATE CHANGE, https://unfccc.int (last visited Jan. 9, 2022).

82 "The U.S. military is an energy guzzler - it is the institution that consumes the most fossil fuels in the world. In fact, its carbon emissions are greater than those of many countries." Leah C. Stokes, A Field Guide for Transformation, in All We CAN SAVE: Truth, Courage, AND Solutions For the Climate CRisis 337, 341 (Ayana Elizabeth Johnson \& Katharine K. Wilkinson eds., 2020). On a more positive note, see MichaEL T. KLARE, All Hell Breaking Loose: The Pentagon's Perspective on Climate Change (2019), which chronicles DoD's under-the-radar "steps to mitigate its contributions to global warming," despite then-President Trump's Executive Order "instruct[ing agencies] to abandon their efforts to enhance climate preparedness." Id. at 1-2; Exec. Order No. 13,783, 82 Fed. Reg. 16,093 (Mar. 31, 2017), https://www.federalregister.gov/documents/2017/03/31/201706576/promoting-energy-independence-and-economic-growth.

83 "It is unequivocal that human influence has warmed the atmosphere, ocean and land. . . Human-induced climate change is already affecting many weather and climate extremes in every region across the globe.... Projected changes in extremes are larger in frequency and intensity with every additional increment of global warming[.]" Intergovernmental Panel on Climate Change, Summary for Policymakers, in Climate Change 2021: The PHYSICAL SCIENCE BASIS 4, 8, 18 (2021), https://www.ipcc.ch/report/ar6/wg1/downloads/report/IPCC_AR6_WGI_SPM final.pdf.

${ }^{84}$ Werhane at

${ }^{85}$ See, e.g., Paul Krugman, The Cult of Selfishness Is Killing America, N.Y. TIMES (July 27, 2020), https://www.nytimes.com/2020/07/27/opinion/us-republicans-coronavirus.html; see also Robin Givhan, Americans Are Stubbornly Unmoved by Death, WASH. POST (Mar. 23, 2021), 
or our children's, best interests? ${ }^{86}$ During the peak of post-9/11 American military activity in Iraq and Afghanistan, we were constantly reminded that ethics and morality are neither as consistent nor as philosophical as the academic thinking in undergraduate classrooms. We publicly celebrate active-duty military but underinvest in veterans' health care and pay lip service to the scourge of post-9/11 veteran suicide. ${ }^{87}$ No number of standing ovations at ball games and concerts compensate for this long-running tragedy.

Bear in mind that those horrific statistics do not include contractor personnel - the anthropomorphic manifestation of Eisenhower's ire - who, for much of the post-millennial era, have not only outnumbered uniformed military in the battlespace, but have paced their level of sacrifice — in terms of injuries and fatalities - as well. ${ }^{88}$ Long before the overdue, brief, and grossly inadequate efforts undertaken by the Biden administration in the summer of 2021, our government (specifically the Departments of Defense and State) consistently hung out to dry and left behind the interpreters and other "battlefield allies, who often braved death threats and put

https://www.washingtonpost.com/nation/2021/03/23/americans-are-stubbornly-unmoved-by-death ("Increasingly it seems that we simply do not care about the other person, that other family, someone else's child. The self is everything. It's freedom and liberty, whims and desires. Community doesn't extend beyond one's front door. Everything else is someone else's concern."); infra note 90. Against that backdrop, see Leo Mackay's implicit yet poignant reminder, in this volume's Foreword, that institutions-government and private, from military services to multinational defense contractors - are communities of individuals. Mackay at _. It is perfectly reasonable to expect those institutions, including Mackay's Lockheed Martin, to "hire ethical people and then train and mentor them on applying ethical principles when they face tough decisions," but it is naïve to suggest that process is the optimal starting point for any discussion of ethical leadership, decision-making, or problem-solving. Id. at 5. Rather, government institutions and private contractors "hope that new employees come with well-tuned moral

compasses ... [calibrated by] lessons ... nurtured in childhood [and] instilled through the higher education system." $I d$. It is only as a last resort, "when all else fails, [that ethical norms must be] enforced by governments." Id.

${ }^{86}$ See, e.g., Ezra Klein, What if American Democracy Fails the Climate Crisis?, N.Y. TIMES (June 22, 2021), https://www.nytimes.com/2021/06/22/magazine/ezra-klein-climate-crisis.html; see also supra text accompanying notes $80-82$.

87 "The overall suicide rate for veterans is 1.5 times as much as the rate for civilians. Among post-Sept. 11 veterans between 18-years-old and 35-years-old, the rate is 2.5 times that of all civilians . ..." Jennifer Steinhauer, Suicides Among Post-9/11 Veterans Are Four Times as High as Combat Deaths, a New Study Finds, N.Y. Times (June 22, 2021), https://www.nytimes.com/2021/06/22/us/911-suicide-rate-veterans.html. See generally National Veteran Suicide Data and Reporting, U.S. DEP'T OF VET. AFF., https://www.mentalhealth.va.gov/suicide prevention/data.asp (last visited Aug. 22, 2021); SAPOLSKY, ET AL., supra note 10, at 288. See also Steven L. Schooner \& Nathaniel E. Castellano, The VA Grand Challenge: Looking for Love in the Wrong Places, Gov. EXEC. (May 20, 2020) https://www.govexec.com/management/2020/05/va-grand-challenge-looking-love-wrong-places/165527.

${ }^{88}$ Steven L. Schooner \& Collin Swan, Dead Contractors: The Un-Examined Effect of Surrogates on the Public's Casualty Sensitivity, 6 J. NAT'L SEC. L. \& POL'Y 11 (2012) (reporting that on the modern battlefield, contractor personnel die at rates similar to-and at times in excess of - soldiers); Steven L. Schooner, Remember Them Too: Don't Contractors Count when We Calculate the Costs of War?, WASH. Post, May 25, 2009, at A21. You are forgiven if this sounds familiar to the way that our Border Patrol callously treated and recklessly separated immigrant parents and children. U.S. GOV'T ACCOUNTABILITY OFF., GAO-20-245, SOUTHWEST BORDER: ACTIONS NEEDED TO IMPROVE DHS PROCESSING OF FAMILIES AND COORDINATION BETWEEN DHS AND HHS (2020), https://www.gao.gov/assets/gao-20-245.pdf (reporting that agents had not correctly recorded family separations and official were unsure of the extent of the problem). 
their families at risk of retribution" in support of American military and diplomatic efforts. ${ }^{89}$ Our failure to educate the public on these issues is, to our minds, an irresponsible, improvident, and short-sighted moral and ethical failure. ${ }^{90}$ This is not to say that we are by nature a fundamentally amoral state or that we are incapable of moral action. But it does serve to remind us that, even if we can summon the appropriate levels of moral courage, none of these issues are easily resolved.

Defense policy is polarizing - not only when engaging in warfare but when preparing for or, hypothetically, avoiding it. But the state's power to wage war-its so-called monopoly over the use of force - plays an outsized role in many of our nation's policies. We are ill-served if we are not constantly thinking, discussing, and, yes, voting on relevant issues. To our minds, this was Eisenhower's ultimate plea: that an "alert and knowledgeable citizenry" "11 would influence our elected leadership to make ethical decisions for the public good. It may seem obvious that, "[i]n a representative democracy, few decisions are more significant or heavily scrutinized than the decision to engage in heavy, sustained, military action abroad."92 But if we do not study and

${ }^{89}$ Editorial Board, America Must Not Turn its Back on Battlefield Allies from Iraq and Afghanistan, WASH. POST (Jan. 30, 2019), https://www.washingtonpost.com/opinions/global-opinions/america-must-not-turn-its-back-onbattlefield-allies-from-iraq-and-afghanistan/2019/01/30/a3c969f4-2317-11e9-81fd-b7b05d5bed90 story.html; Helene Cooper \& Eric Schmitt, U.S. to Move Afghans Who Aided Troops Outside the Country, N.Y. TIMES (June 24, 2021), https://www.nytimes.com/2021/06/24/us/politics/afghan-interpreters-visas.html ("More than 18,000 Afghans who have worked as interpreters, drivers, engineers, security guards, fixers and embassy clerks for the United States during the war [and their 53,000 family members] have been trapped in bureaucratic limbo after applying for special immigrant visas, available to people who face threats because of work for the U.S.

government."). On a slightly positive note, the controversy surrounding the 2021 removal of U.S. armed forces from Afghanistan served to ever so fleetingly insert some of these issues into the public consciousness. Mark Cancian, In Afghanistan, Contractors Were Unsung Heroes of US Efforts, BREAKING DEF. (Aug. 30, 2021), https://breakingdefense.com/2021/08/in-afghanistan-contractors-were-unsung-heroes-of-us-efforts.

${ }^{90}$ This critique applies across the policy spectrum. See generally Kayla Chadwick, I Don't Know How to Explain to You that You Should Care About Other People: Our Disagreement Is Not Merely Political, but a Fundamental Divide on What it Means to Live in a Society, HuFFPost (June 26, 2017), https://www.huffpost.com/entry/i-dontknow-how-to-explain-to-you-that-you-should_b_59519811e4b0f078efd98440.

${ }^{91}$ To place that quote in context, Eisenhower said,

In the councils of government, we must guard against the acquisition of unwarranted influence, whether sought or unsought, by the military-industrial complex. The potential for the disastrous rise of misplaced power exists and will persist. We must never let the weight of this combination endanger our liberties or democratic processes. ... Only an alert and knowledgeable citizenry can compel the proper meshing of the huge industrial and military machinery of defense with our peaceful methods and goals, so that security and liberty may prosper together.

Eisenhower, supra note 13, at 1035.

${ }^{92}$ Schooner \& Swan, supra note 88, at 11. During this book's final editing stage, the 2021 withdrawal of armed forces from Afghanistan thrust these issues into the public domain. See generally Ted Van Green \& Carroll Doherty, Majority of U.S. Public Favors Afghanistan Troop Withdrawal; Biden Criticized for His Handling of Situation, PEW RSCH. CTR. (Aug. 31, 2021), https://www.pewresearch.org/fact-tank/2021/08/31/majority-of-u-s-public-favorsafghanistan-troop-withdrawal-biden-criticized-for-his-handling-of-situation ("[T] here is notable agreement among members of both parties that the U.S. mostly failed in achieving its goals in Afghanistan. Nearly identical majorities of Republicans (70\%) and Democrats (69\%) say the U.S. failed to accomplish its goals there."). See also Catie Edmonson, Lawmakers Unite in Bipartisan Fury over Afghanistan Withdrawal, N.Y. TIMES (Aug. 16, 2021), 
discuss the relevant issues and policies, how can we expect to rely on our citizenry to push leadership in the right direction?

All of this brings us back to where Schoeni and Vestner began in the Introduction, with a compelling analogy to the law of war:

Consider how this relates to the law of war, which governs how wars are conducted (jus in bello). This volume assumes that wars will continue and that a large share of global wealth will be devoted to the manufacture of arms for the foreseeable future. Though industry is temporally and physically removed from the battlefield, how and in what manner it equips forces are questions of great moral significance, effectively questions about jus in bello. Just as soldiers are judged for their conduct in battle, so also can industry be held to account for the acquittal of its duties. Jus in bello is designed to limit the suffering caused by war. In a similar fashion, studying the moral questions about the manufacture, sale, and distribution of arms may teach us how to curtail any unnecessary harm that this bloody industry causes. Such an industry must exist, but its ethical shortcomings can be identified, studied, and perhaps even mitigated. ${ }^{93}$

Just as the transparency community advocates that "sunlight is the best disinfectant,"94 the academic community is well served to keep scholars and students talking and thinking about the defense industry, warts and all. The thorny issues discussed in this volume challenge us to think, force us to ask difficult questions, and evade simple resolution. But they are also far too important for a representative democracy - a government of the people - to take for granted. If academic institutions aspire to remain robust marketplaces of ideas, teachers, students, and scholars must keep the discussion going.

https://www.nytimes.com/2021/08/16/us/politics/afghanistan-withdrawal-congress.html; Peter Nicholas, Biden Is Betting Americans Will Forget About Afghanistan, ATLANTIC (Aug. 20, 2021), https://www.theatlantic.com/politics/archive/2021/08/biden-afghanistan-midterms/619838 ("For all the intense focus in Washington on the Taliban's resurgence, the broader public seems more preoccupied with other issues, like the still-raging coronavirus pandemic. ... One former Biden campaign aide [noted that], ' $\ldots$ at the end of the day, voters care about things that affect them and their families."').

${ }^{93}$ Schoeni \& Vestner at

${ }^{94}$ One longs for the day when readers will have forgotten (or never knew) that it was during the Trump administration that the Washington Post added "Democracy Dies in Darkness" to its masthead. See Wash. Post, https://www.washingtonpost.com (last visited Jan. 9, 2022). 


\section{Works Cited}

Interagency Suspension and Debarment Committee (ISDC), ACQUISITION.GOV, https://www.acquisition.gov/isdc-home (last visited Jan. 9, 2022)

Steven Aftergood, The Costs of War: Obstacles to Public Understanding, FED'N OF AM. SCIENTISTS (Nov. 14, 2018), https://fas.org/sgp/eprint/costs.pdf

Tom Ambrose, World's Militaries Avoiding Scrutiny over Emissions, Scientists Say, GUARDIAN (Nov. 11, 2021), https://www.theguardian.com/environment/2021/nov/11/worlds-militariesavoiding-scrutiny-over-emissions

Gun Violence Is a Public Health Crisis, Am. Pub. Health Ass'N, https://www.apha.org//media/Files/PDF/factsheets/200221 Gun Violence Fact Sheet.ashx (last visited Jan. 9, 2022)

Katherine Barrett \& Richard Greene, Making Government Work: The Promises And Pitfalls of PERFORMANCE-INFORMED MANAGEMENT (2020)

Letter from Noah Bookbinder, President, Citizens for Resp. \& Ethics, et al., to Bill Schmidt, Suspension \& Debarment Off., Gen. Servs. Admin., et al. (Oct. 12, 2021), https://www.citizensforethics.org/wp-content/uploads/2021/10/2021-10-12-Trump-OrganizationSuspension-Referral.pdf

Boston Dynamics, Do You Love Me?, YouTUBE (Dec. 29, 2020), https://www.youtube.com/watch?v=fn3KWM1kuAw

David Brancaccio, Rose Conlon \& Candace Manriquez Wrenn, How Police Departments Got Billions of Dollars of Tactical Military Equipment, MARKETPLACE (June 12, 2020), https://www.marketplace.org/2020/06/12/police-departments-1033-military-equipment-weapons

Mark Cancian, In Afghanistan, Contractors Were Unsung Heroes of US Efforts, BREAKING DEF. (Aug. 30, 2021), https://breakingdefense.com/2021/08/in-afghanistan-contractors-were-unsungheroes-of-us-efforts

Kayla Chadwick, I Don't Know How to Explain to You that You Should Care About Other People: Our Disagreement Is Not Merely Political, but a Fundamental Divide on What it Means to Live in a Society, HufFPost (June 26, 2017), https://www.huffpost.com/entry/i-dont-knowhow-to-explain-to-you-that-you-should b 59519811e4b0f078efd98440

John Cibinic, JR., James F. NAgle \& Ralph C. NASh, JR., Administration OF Government CONTRACTS 697-790 (5th ed. 2016)

Critical Infrastructure Sectors, CyBERSECURITy \& INFRASTRUCTURE SEC. AGENCY, https://www.cisa.gov/defense-industrial-base-sector (last visited Jan. 9, 2022) 
Helene Cooper \& Eric Schmitt, U.S. to Move Afghans Who Aided Troops Outside the Country, N.Y. TIMES (June 24, 2021), https://www.nytimes.com/2021/06/24/us/politics/afghaninterpreters-visas.html

Michael Davis, Ruck Up: An Introduction to the Legal Issues Associated with Civilian Contractors on the Battlefield, 29 PUB. CoNT. L.J. 233 (2000)

DeF. Indus. InitiAtive On Bus. ETHICS \& CONDUCT, https://www.dii.org (last visited Aug. 22, 2021)

1033 Program FAQs, Def. Logistics AgENCY, https://www.dla.mil/DispositionServices/Offers/Reutilization/LawEnforcement/ProgramFAQs.as px (last visited Aug. 22, 2021)

Foreign Military Sales FAQ, DEF. SEC. COOP. AGENCY, https://www.dsca.mil/foreign-militarysales-faq (last visited Aug. 22, 2021)

Pentagon Facts, U.S. DEP'T OF DEF., https://pentagontours.osd.mil/Tours/facts.html

Directorate of Defense Trade Controls, U.S. DEP'T OF STATE,

https://www.pmddtc.state.gov/ddtc_public (last visited Jan. 9, 2022)

National Veteran Suicide Data and Reporting, U.S. DEP'T OF VET. AfF.

https://www.mentalhealth.va.gov/suicide_prevention/data.asp (last visited Aug. 22, 2021)

Bruce Drake, On Memorial Day, Public Pride in Veterans, but at a Distance, Pew Rsch. Ctr. (May 24, 2013), https://www.pewresearch.org/fact-tank/2013/05/24/on-memorial-day-publicpride-in-veterans-but-at-a-distance-2/

Richard L. Dunn, Defense Industry Needs New Way of Doing Business, NAT'L Def. (Nov. 6, 2000), https://www.nationaldefensemagazine.org/articles/2020/11/6/defense-industry-needsnew-way-of-doing-business

Catie Edmonson, Lawmakers Unite in Bipartisan Fury over Afghanistan Withdrawal, N.Y. TIMES (Aug. 16, 2021), https://www.nytimes.com/2021/08/16/us/politics/afghanistanwithdrawal-congress.html

Dwight D. Eisenhower, Farewell Radio and Television Address to the American People (Jan. 17, 1961), in Public Papers of the President of the United States: Dwight D. Eisenhower 1960-61, at 1035 (1961)

Sheri Fink, Settlement Reached in C.I.A. Torture Case, N.Y. TIMES (Aug. 17, 2017), https://www.nytimes.com/2017/08/17/us/cia-torture-lawsuit-settlement.html 
Conor Friedersdorf, The Destructiveness of Call-Out Culture on Campus, ATLANTIC (May 8, 2017), https://www.theatlantic.com/politics/archive/2017/05/call-out-culture-is-stressing-outcollege-students/524679

What is DCAF, GENEVA CTR. FOR SEC. SECTOR GOVERNANCE, https://dcaf.ch/about-us (last visited Jan. 9, 2022)

Ed Gerrish, The Impact of Performance Management in Public Organizations: A Meta-Analysis, 76 Pub. Admin. ReV. 48 (2015)

Robin Givhan, Americans Are Stubbornly Unmoved by Death, WASH. Post (Mar. 23, 2021), https://www.washingtonpost.com/nation/2021/03/23/americans-are-stubbornly-unmoved-by$\underline{\text { death }}$

U.S. Gov't ACCOUNTABILITy OfF., GAO-17-797SP, Availability of Appropriations: Purpose, in PRINCIPLES OF FEDERAL APPROPRIATIONS LAW 3-1, 3-9 (4th ed. 2017) (quoting 31 U.S.C. $\S$ 1301(a)), https://www.gao.gov/assets/2019-11/687162.pdf

U.S. Gov'T AcCountability OfF., GAO-20-245, SOUthwest Border: ACtions NeEded to IMPROVE DHS PROCESSING OF FAMILIES AND COORDINATION BETWEEN DHS AND HHS (2020), https://www.gao.gov/assets/gao-20-245.pdf

U.S. Gov't ACCOUnTABILITy OFF., GAO-22-104679, DeFEnSE CONTRACTOR CYBERSECURITY: STAKEHOLdER COMMUNiCATION AND PERFormance GOAls COULd IMPROVE CERTIFICATION FRAMEWORK (2021), https://www.gao.gov/assets/gao-22-104679.pdf

Auditing and Financial Management, U.S. Gov't AccountABILITY OfF., https://www.gao.gov/topics/auditing-and-financial-management (last visited Oct. 7, 2021)

Budgeting and Spending, U.S. Gov'T ACCOUNTABILITY OFF., https://www.gao.gov/topics/budget-and-spending (last visited Oct. 7, 2021)

High Risk List, U.S. GOV’T ACCOUNTABILITY OFF., https://www.gao.gov/high-risk-list (last visited Oct. 7, 2021)

National Defense, U.S. Gov'т ACCOUNTABILITY OFF., https://www.gao.gov/topics/nationaldefense (last visited Oct. 7, 2021),

Veterans, U.S. Gov'T ACCOUNTABILITY OFF., https://www.gao.gov/topics/veterans (last visited Oct. 7, 2021)

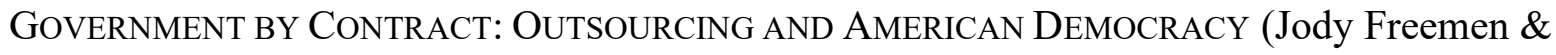
Martha Minow eds., 2009)

Ted Van Green \& Carroll Doherty, Majority of U.S. Public Favors Afghanistan Troop Withdrawal; Biden Criticized for His Handling of Situation, PEW RsCH. CTR. (Aug. 31, 2021), 
https://www.pewresearch.org/fact-tank/2021/08/31/majority-of-u-s-public-favors-afghanistantroop-withdrawal-biden-criticized-for-his-handling-of-situation

Erico Guizzo, How Boston Dynamics Is Redefining Robot Agility, IEEE Spectrum (Nov. 27, 2019), https://spectrum.ieee.org/how-boston-dynamics-is-redefining-robot-agility

Michaila Hancock, Pentagon: The World's Largest Office Building - in Infographics, ARCHITECT's J. (Aug. 27, 2015), https://www.architectsjournal.co.uk/news/pentagon-the-worldslargest-office-building-in-infographics

William D. Hartung, Saint Augustine's Rules: Norman Augustine and the Future of the American Defense, 13 WORLD POL’Y J. 65 (1996)

Falih Hassan \& Jane Arraf, Blackwater's Bullets Scarred Iraqis. Trump's Pardon Renewed the Pain, N.Y. TIMES (Dec. 23, 2020), https://www.nytimes.com/2020/12/23/world/middleeast/blackwater-trump-pardon.html

Reestablish the Golden Fleece Award, 161 Cong. Rec. H3397 (daily ed. May 20, 2015) (statement of Rep. Hill), https://www.congress.gov/congressional-record/2015/05/20/housesection/article/H3397-2

Intergovernmental Panel on Climate Change, Summary for Policymakers, in Climate Change 2021: The Physical Science Basis 4, 8, 18 (2021), https://www.ipcc.ch/report/ar6/wg1/downloads/report/IPCC_AR6_WGI_SPM_final.pdf

Private Military and Security Companies: Implementation of Montreux Document, InT'L ComM. OF THE RED CROSS (Dec. 16, 2014), https://www.icrc.org/en/document/private-military-andsecurity-companies-implementation-montreux-document

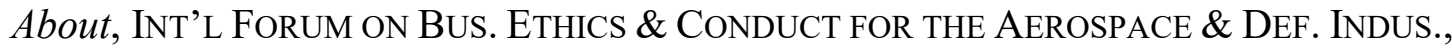
https://ifbec.info/about (last visited Aug. 22, 2021).

INT'L STABILITY OPERATIONS AsS'N, https://stability-operations.org (last visited Aug. 22, 2021)

JAws (Universal 1975), available at https://www.youtube.com/watch?v=u9S41Kplsbs

John Kamensky, Does Performance Matter?, IBM CTR. FOR Bus. Gov’T (Mar. 28, 2016), https://www.businessofgovernment.org/blog/does-performance-matter

Sarah Kendzior, Hiding in Plain Sight: The Invention of Donald TrumP And the EROSION OF AMERICA (2020)

Special Briefing with Patrick F. Kennedy, Ambassador, Dep't of State, on the Report of the Secretary of State's Panel on Personal Protective Services in Iraq (Oct. 23, 2007), https://20012009.state.gov/r/pa/prs/ps/2007/oct/94019.htm 
Ben Kesling, Semper Dry: Now Marines Can Carry Umbrellas, Setting Off Stormy Debate, WALL ST. J. (Nov. 11, 2019), https://www.wsj.com/articles/semper-dry-now-marines-can-carryumbrellas-setting-off-stormy-debate-11573494284

Michael T. Klare, All Hell Breaking loose: The Pentagon's Perspective on Climate CHANGE (2019)

Ezra Klein, What if American Democracy Fails the Climate Crisis?, N.Y. TIMES (June 22, 2021), https://www.nytimes.com/2021/06/22/magazine/ezra-klein-climate-crisis.html

Paul Krugman, The Bogus Bashing of Build Back Better, N.Y. TIMES (Dec. 13, 2021), https://www.nytimes.com/2021/12/13/opinion/build-back-better.html

Paul Krugman, The Cult of Selfishness Is Killing America, N.Y. TIMES (July 27, 2020), https://www.nytimes.com/2020/07/27/opinion/us-republicans-coronavirus.html

Danielle Kurtzleben, Trump Embraces One of Russia's Favorite Propaganda Tactics Whataboutism, NPR (Mar. 17, 2017), https://www.npr.org/2017/03/17/520435073/trumpembraces-one-of-russias-favorite-propaganda-tactics-whataboutism

Doug Lederman, Wrangling over Military Recruiting, INSIDE HIGHER ED (Feb. 3, 2005), https://www.insidehighered.com/news/2005/02/03/wrangling-over-military-recruiting

JOHN LENNON, Imagine, on IMAGINE (Apple Records1971)

It Will Be a Great Day When Our Schools Get All the Money They Need and the Air Force Has to Hold a Bake Sale to Buy a Bomber, LiBR. OF CONG., https://www.loc.gov/resource/ds.13124 (last visited Jan. 9, 2022)

Paul C. Light, The Government-Industrial Complex: The True Size of the Federal GOVERNMENT, 1984-2018 (2019)

Code of Conduct, LOCKHEED MARTIN, https://www.lockheedmartin.com/en-us/who-weare/ethics/code-of-ethics.html (last visited Jan. 9, 2022)

The Magic School Bus (Scholastic 1994-1997)

Jean Marbella, ROTC Resurgent on College Campuses Where Once Scorned, BALT. Sun, (Nov. 18, 2001), https://www.baltimoresun.com/news/bs-xpm-2001-11-18-0111180052-story.html

Sean McFate, The Modern Mercenary: Private Armies and What They Mean for WORLD ORDER (2015)

Hiroshima and Nagasaki Exhibit, NAT'L Museum OF NuClEAR SCI. \& Hist., https://www.nuclearmuseum.org/see/exhibits/hiroshima-and-nagasaki (last visited Jan. 9, 2022) 
Peter Nicholas, Biden Is Betting Americans Will Forget About Afghanistan, AtLantiC (Aug. 20, 2021), https://www.theatlantic.com/politics/archive/2021/08/biden-afghanistan-midterms/619838

Andy Norman, The Cause of America's Post-Truth Predicament, SCI. AM. (May 18, 2021), https://www.scientificamerican.com/article/the-cause-of-americas-post-truth-predicament

Pippa Norris, Cancel Culture: Myth or Reality?, PoL. STUD., July 16, 2021, at 1, https://journalssagepub-com.proxygw.wrlc.org/doi/pdf/10.1177/00323217211037023

Senate Vote Means End of Renegotiation Board, N.Y. TIMES (Apr. 3, 1979), https://www.nytimes.com/1979/04/03/archives/senate-vote-means-end-of-renegotiationboard.html

Anti-Corruption \& Integrity Hub, OECD, https://www.oecd.org/corruption-integrity (last visited Aug. 22, 2021)

Renegotiation Board-Reporting Requirement (50 U.S.C. App. § 1215)—Effect of Absence of an Appropriation-Repeals by Implication, 3 Op. O.L.C. 318 (1979), https://www.justice.gov/file/22096/download

Derek O'Malley \& Andrew Hill, Close Air Support in 2030: Moving Beyond the A-10/F-35 Debate, WAR ON THE ROCKS (May 28, 2015), https://warontherocks.com/2015/05/the-a-10-the-f35-and-the-future-of-close-air-support-part-ii

Michael Leo Owens, Tom Clark \& Adam Glynn, Where Do Police Departments Get Their Military-Style Gear? Here's What We Don't Know, WASH. Post (July 20, 2020), https://www.washingtonpost.com/politics/2020/07/20/where-do-police-departments-get-theirmilitary-style-gear-heres-what-we-dont-know

Heidi M. Peters, Cong. Rsch. Serv., IF10548, Defense Primer: U.S. Defense Industrial BASE (2021), https://crsreports.congress.gov/product/pdf/IF/IF10548/10

Heidi M. Peters, Cong. Rsch. SERV., R46643, Defense Acquisitions: DOD's Cybersecurity MATURITY MODEL CERTIFICATION FRAMEWORK (2020), https://crsreports.congress.gov/product/pdf/R/R46643/2

Elizabeth Phelan, "A Watershed Moment": Reflecting on the Burning of the ROTC Air Force Building-50 Years Later, STUDENT LIFE (May 5, 2020), https://www.studlife.com/scene/2020/05/05/a-watershed-moment-reflecting-on-the-burning-ofthe-rotc-air-force-building-50-years-later

Rachel Augustine Potter, Macro Outsourcing: Evaluating Government Reliance on the Private Sector, J. POL. (forthcoming), https://ssrn.com/abstract=3907539

William L. Prosser, Lighthouse No Good, 1 J. LEGAL EduC. 257, 257 (1948) 
Annalisa Quinn, Chinua Achebe and the Bravery of Lions, NPR (Mar. 23, 2013), https://www.npr.org/sections/thetwo-way/2013/03/22/175046327/chinua-achebe-and-thebravery-of-lions

Kate Raworth, Doughnut ECONOMics 123 (2017)

Roger Riddell, Can Higher Ed Really Affect Change Through Divestment?, HigHER Ed Dive (May 29, 2014), https://www.highereddive.com/news/can-higher-ed-really-affect-changethrough-divestment/265675

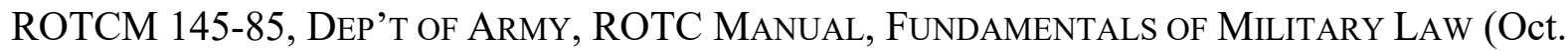
1980)

Gregory Sanders et al., Defense Contract Trends: U.S. Department of Defense Contract Spending and the Supporting Industrial Base, CTR. FOR STRATEGIC \& INT'L STUD. (2011), https://www.csis.org/analysis/defense-contract-trends-0

Harvey M. Sapolsky, Eugene Gholz \& Caitlin Talmadge, U.S Defense Politics: The ORIGINS OF NATIONAL SECURITY (4th ed. 2021)

Steven L. Schooner, Contractor Atrocities at Abu Ghraib: Compromised Accountability in a Streamlined, Outsourced Government, 16 STAN. L. \& POL'Y REV. 549 (2005)

Steven L. Schooner, Remember Them Too: Don't Contractors Count when We Calculate the Costs of War?, WASH. Post, May 25, 2009, at A21

Steven L. Schooner, The Well-Reasoned Case for Reversing the Outsourcing Trend: A Review Essay of Jon Michaels' CONSTITUTIONAL COUP: PRIVATIZATION's THREAT TO THE AMERICAN REPUBLIC, 59 GOV'T CONTRACTOR | 319 (2017)

Steven L. Schooner, We Need to Talk About Corruption, Gov’T EXEC. (Sept. 29, 2020) (reviewing Jennifer TAub, Big DirTy Money: The SHocking InJustice AND Unseen Cost of White COLlar CRIME (2020)), https://www.govexec.com/management/2020/09/we-need-talkabout-corruption/168857

Steven L. Schooner \& Nathaniel E. Castellano, Review Essay: Reading THE DrEAM MACHINE: The Untold StORY OF THE Notorious V-22 OsPREY, by Richard Whittle, in Light of the Defense Acquisition Performance Study, 43 PuB. ConT. L.J. 391 (2014)

Steven L. Schooner \& Nathaniel Castellano, Dawn of the Intercontinental Sniper: The Drone's Cascading Contribution to the Modern Battlefield's Complexity, 8 J. NAT'L SEC. L. \& POL'Y 321 (2016) (reviewing Richard WhitTle, PredATOR: The SECRET Origins OF THE DronE REVOLUTION (2014))

Steven L. Schooner \& Nathaniel E. Castellano, The VA Grand Challenge: Looking for Love in the Wrong Places, Gov. EXEC. (May 20, 2020) 
https://www.govexec.com/management/2020/05/va-grand-challenge-looking-love-wrongplaces/165527

Steven L. Schooner, Kathleen Clark \& Scott Amey, Suspend the Trump Organization from Doing Business with Government, Gov'T EXEC. (Jan. 27, 2020), https://www.govexec.com/management/2020/01/viewpoint-suspend-trump-organization-doingbusiness-government/162672

Steven L. Schooner \& Daniel S. Greenspahn, Too Dependent on Contractors? Minimum Standards for Responsible Governance, 6 J. ConT. MGMT. 9 (2008)

Steven L. Schooner \& Collin Swan, Dead Contractors: The Un-Examined Effect of Surrogates on the Public's Casualty Sensitivity, 6 J. NAT'L SEC. L. \& POL'y 11 (2012)

Historical Timeline, SELECTIVE SERV. SYS., https://www.Sss.gov/history-and-records/timeline (last visited Jan. 9, 2022)

Allison Stanger, One Nation Under Contract: The Outsourcing of American Power AND THE FUTURE OF FOREIGN POLICY (2011)

DOUG StANTON, In HARM’s WAY (2001)

Samuel Stebbins \& Evan Comen, Military Spending: 20 Companies Profiting the Most from War, USA TODAY (Feb. 21, 2019), https://www.usatoday.com/story/money/2019/02/21/militaryspending-defense-contractors-profiting-from-war-weapons-sales/39092315

Jennifer Steinhauer, Suicides Among Post-9/11 Veterans Are Four Times as High as Combat Deaths, a New Study Finds, N.Y. TIMES (June 22, 2021), https://www.nytimes.com/2021/06/22/us/911-suicide-rate-veterans.html

Leah C. Stokes, A Field Guide for Transformation, in All We Can SAVE: Truth, Courage, AND SOlUtions FOR THE ClimATE CRISIS 337 (Ayana Elizabeth Johnson \& Katharine K. Wilkinson eds., 2020)

Mike Stone, The Warthog and the Senator: The Politics of Retiring a Warplane, ReuTERS (July 16, 2021), https://www.reuters.com/world/us/warthog-senator-politics-retiring-warplane-2021$\underline{07-16}$

John A. Tirpak, Druyun's Downfall, AIR ForCe MAG.: WASH. WATCH (Nov. 1, 2004), https://www.airforcemag.com/article/1104watch

What Is Defence and Security and Corruption?, TRANSPARENCY INT'L, https://www.transparency.org/en/our-priorities/defence-and-security (last visited Aug. 22, 2021)

Public Procurement, TRANSPARENCY InT'L, https://www.transparency.org/en/ourpriorities/public-procurement (last visited Aug. 22, 2021) 
2021 Power Rankings, U.S. News \& WorLd ReP., https://www.usnews.com/news/bestcountries/power-rankings (last visited Aug. 22, 2021)

Glasgow Climate Change Conference, U.N. Climate CHANGE, https://unfccc.int (last visited Jan. 9, 2022)

Chiara Vercellone, Who Were the Largest Major Arms Exporters in the Last 5 Years?, DeF. NEws (Mar. 9, 2020), https://www.defensenews.com/2020/03/09/who-were-the-largest-majorarms-exporters-in-the-last-5-years

Rebecca R. Vernon, Battlefield Contractors: Facing Tough Issues, 33 PUB. ConT. L.J. 369 (2004)

America's Longest War: A Visual History of 19 Years in Afghanistan, WaLl ST. J. (Apr. 18, 2021), https:/www.wsj.com/articles/us-longest-war-afghanistan-11583010024

Laurel Wamsely, Shock and Dismay After Trump Pardons Blackwater Guards Who Killed 14 Iraqi Civilians, NPR (Dec. 23, 2020), https://www.npr.org/2020/12/23/949679837/shock-anddismay-after-trump-pardons-blackwater-guards-who-killed-14-iraqi-civil

Editorial Board, America Must Not Turn its Back on Battlefield Allies from Iraq and Afghanistan, WASH. POST (Jan. 30, 2019), https:/www.washingtonpost.com/opinions/globalopinions/america-must-not-turn-its-back-on-battlefield-allies-from-iraq-andafghanistan/2019/01/30/a3c969f4-2317-11e9-81fd-b7b05d5bed90 story.html

WASH. Post, https://www.washingtonpost.com (last visited Jan. 9, 2022)

Andrew Lloyd Webber \& Tim Rice, Could We Start Again Please?, on Jesus Christ SUPERSTAR (MCA Records 1973)

Richard G. Weingardt, Norman Ralph Augustine, 9 LEADERSHIP \& MGMT. ENG'G 149 (2009)

Charles Edward White, The Enlightened Soldier: Scharnhorst And the MiLitarische GESELLSCHAFT IN BERLIN, 1801-1805 (1989)

Craig Whitlock \& Kevin Uhrmacher, Prostitutes, Vacations and Cash: The Navy Officials "Fat Leonard” Took Down, WASH. PosT (Sept. 20, 2018), https://www.washingtonpost.com/graphics/investigations/seducing-the-seventh-fleet/

Billy Witz, How a Military Prep School Helped Army Improve in Football, N.Y. TIMES (Sept. 22, 2019), https://www.nytimes.com/2019/09/09/sports/army-prep-school.html

Robert Woodard, Bureau of Indus. \& Sec., DeP’'t of Com., OfFsets in Defense Trade FREQUENTLY ASKED QUESTIONS (2017), https://www.bis.doc.gov/index.php/documents/pdfs/1677-offsets-in-defense-trade-faqs-final/file 
David Zucchino \& David S. Cloud, Special Report: U.S. Military and Civilians Are Increasingly Divided, L.A. TIMES (May 23, 2015), https://www.latimes.com/nation/la-na-warrior-main20150524-story.html 